Residual state ownership and stock market integration: Evidence from Chinese partly privatised firms

\author{
Hong Li \\ Nottingham University Business School \\ University of Nottingham \\ Nottingham NG8 1BB \\ United Kingdom \\ hong.li@nottingham.ac.uk \\ Tel: $+44(0) 115784148$ \\ Fax: $+44(0) 1158466667$
}




\title{
Residual state ownership and stock market integration: Evidence from Chinese partly- privatised firms
}

\begin{abstract}
This paper assesses China's integration with the global stock market over its privatisation process, by examining the asset pricing mechanisms of Chinese firms under different levels of state ownership within a two-beta CAPM framework. We derive time-varying national and global systematic risks for the portfolios compiled on the basis of residual state ownership and examine how these risks are priced while controlling for structural changes exogenously and endogenously. Through anchoring our analysis to the portfolios capturing this institutional factor, we observe mostly positive pricing of the systematic risks, instead of the negative pricing often found in the literature on emerging markets. Within this wellcontrolled framework, some interesting points emerge. While full privatisation does not eliminate exposure to the national systematic risk, more heavily privatised firms (i.e., those with the least residual state ownership) tend to price only the global risk more often than less privatised ones. Hence, among partly-privatised firms, integration with the global market strengthens as state ownership decreases. These results suggest that emerging economies pursue rigorous privatisation and yet governments keep small stakes in privatised firms in order to ensure integration with the global market.
\end{abstract}

JEL classification: C32, F36, G12, G15

Key words: state ownership; political interference; asset pricing; stock market integration; Kalman smoothing; regime switching; 


\section{Introduction}

Emerging economies around the world pursue privatisation for the benefits of improved efficiency, reduction of public debt and/or better access to equity capital. However, inflow of portfolio investments depends on whether the emerging stock markets are integrated with the global market. Although integrated stock markets may be more volatile, funds for these markets are more readily available at lower costs. It is of interest to examine whether emerging stock markets could be more integrated with the global market if political authorities were less significantly involved in firm governance. This paper, therefore, attempts to control for residual state ownership in the assessment of China's integration with the global stock market within an augmented CAPM framework in the style of Jorion and Schwartz (1986). As China has many of the typical characteristics of emerging markets, the study of the role of residual state ownership in stock market integration will produce useful policy implications for emerging economies.

Within the chosen asset-pricing framework, stock market integration is defined as a situation where investors earn the same risk-adjusted expected return on similar portfolios in local and global markets. Hence, the investigation of market integration for a particular economy, in principle, involves testing whether systematic risk relative to the global market is the only significant factor in an asset pricing model, when both global and national systematic risks are controlled for. This definition of stock market integration is in stark contrast to the less theoretically based statistical interdependence that is widely used in the existing literature on integration between national stock markets. However, many studies in the context of asset pricing (e.g., Mo and $\mathrm{Wu}, 2007$; Omran, 2007 and Li, 2013) commonly find negative risk pricing, especially the pricing of the national systematic risk, for emerging markets. Negative risk pricing is inconsistent with the theory of risk aversion and suggests that investors will not be compensated for taking on risky investment projects. Haugen (1999) attributes the 
negative trade-off between return and risk to the omission of a size or liquidity premium effect in the CAPM model. It is also possible that the negative risk pricing in emerging markets is due to the omission of the risk of political interference, given that Diamonte et al. (1996), Erb et al. (1996) and Bekaert et al. (1997) find that in most emerging markets, political risk is a priced factor for which investors are rewarded.

We accept that these potentially omitted risk factors might not be diversified away as assumed by the modern portfolio theory, so in this paper, we will take these factors into account when assessing stock market integration within the well-developed two-beta CAPM framework. However, we will not simply add these risk factors to the two-beta asset-pricing model that is already based on a sound theoretical definition of stock market integration. Our practice is based on econometric considerations. If we do not know any 'true' model alternative to this two-beta asset-pricing model, adding more factors to the existing model will not help unless we could exhaust the list of omitted variables that need to be considered. There are also practical difficulties to proxy properly or quantify these omitted risk factors for empirical studies. For example, political risk is typically measured by ratings that relate to restrictions on the repatriation of profits, exchange control or the risk of expropriation and contract repudiation by governments. These national ratings cannot be applied to studies of asset pricing at the firm level within countries. Another example is liquidity risk. Liquidity refers to the degree to which assets can be liquidated over a short period of time at minimal cost with minimum price impact. Although a multitude of liquidity proxies can be found in the literature, Bernstein (1987) argues that no single measure tells the whole story of liquidity. Instead we will control for these factors by anchoring our analysis to portfolios, whose constituent stocks are selected in such a way that they have similar levels of these omitted risks within portfolios and distinct levels of the risks between portfolios. 
Residual state ownership is a major institutional characteristic of emerging economies and it is likely to be associated with potential risks omitted from the two-beta CAPM framework as documented in the section of review of the literature. Hence, in this paper, we will use the extent of residual state ownership as the criterion to compile portfolios in order to control for risks of political interference and liquidity. Specifically, we compile portfolios to represent the firms that have been privatised to different degrees, e.g., the firms falling in the bottom, middle and upper quartiles of the state ownership distribution during January 2000 to December 2011. The constituent stocks of the portfolios are permitted to change over time, i.e., to leave or join a portfolio according to their percentage of state-owned shares each year, ensuring that the stocks within portfolios have similar levels of potential risks over time. For comparison purposes, we also generate portfolios of shares, respectively, from firms that have never been owned by the state and firms that have been fully privatised. For all portfolios, we weigh their constituent stocks with their market capitalisation, further controlling for heterogeneity in market activity and size within portfolios. Selecting portfolios representing firms under different levels of state ownership as the anchor of our analysis has therefore both empirical and economic appeal. With similar strategic importance, shares within such portfolios have similar liquidity risk and political risk, ensuring fair tests of their exposures to the global and national systematic risks across portfolios within the twobeta CAPM framework. By contrasting the test results between portfolios, we can observe whether residual state ownership hinders stock market integration additionally.

The empirical work in this paper will entail firstly the derivation of time-invariant and timevarying global and national systematic risks for these portfolios using OLS and Kalman smoothing techniques respectively and secondly the examination of how the national and global systematic risks are priced by these portfolios in a time-varying setting. We will ensure that structural changes in the sample period are controlled for exogenously through a 
dummy variable approach and endogenously by the Markov regime-switching technique respectively. Compared with the conventional two-pass or simultaneous time-series crosssection regression analysis in the literature, these statistical techniques will help address the concerns of financial economists that the behaviour of beta risks is not constant over time and that risk prices can be altered by policy changes or crises.

We contribute to the literature in several important ways. Firstly, we propose to take into account the institutional factor of state ownership when testing for stock market integration between emerging economies and the global market. We successfully incorporate potential risks, such as liquidity and political interference, into the two-beta CAPM framework by anchoring our analysis to the unique portfolios that represent different levels of state ownership of an emerging market like China. Although many studies have been carried out on the influence of China's state ownership on corporate operating performance (see Fan et al., 2014), to the best of our knowledge, our work is the first to explore whether residual state ownership alters firms' exposures to the national and global systematic risks. As we aim to detect changes in the degree of China's integration with the global market over its privatisation process, our work is also different from Wang and Di Iorio (2007) and Li (2013) who study China's stock market integration in relation to whether foreign investors are restricted or not. Lastly, we stratify the whole sample to enable the contrast of the asset pricing mechanisms between fully- and partly-privatised firms as well as among the partlyprivatised firms and deduce a non-linear relationship, which is missing in the literature but needed for policy making, between ownership structure and stock market integration. Our findings about this relationship will enable emerging economies to design a privatisation programme that is most likely to result in integration with the global market and reap the benefits associated with integration, such as lower cost of capital and greater investment funds. 
The remainder of the paper is organised as follows. We review the literature in section 2 and describe the empirical framework in section 3 . We generate the unique portfolios and carry out the preliminary data analysis in section 4. Estimation and tests are implemented in section 5 and finally, in section 6 we provide our conclusions.

\section{Review of the literature}

Most studies on stock market integration are conducted through cointegration or correlation analysis of market indices or returns. However the existence of a long-run relationship or correlation between national markets does not prove stock market integration. Recently, a number of studies on China's stock market integration have been carried out in the context of asset-pricing models. Following Jorion and Schwartz (1986), Wang and Di Iorio (2007) and Li (2013) have tested for China's stock market integration within the framework of an augmented CAPM. While Wang and Di Iorio (2008) do not find any evidence of integration, Li (2013) finds that China's once-restricted A-share market tends to be more integrated with the global market than the unrestricted B-share market. Commonly, these studies have overlooked the ownership structure of Chinese firms. Although privatisation is deepening, most of the Chinese firms are still partly owned by the government, which holds the power to interfere.

\subsection{Firm characteristics and state ownership in China}

Over the years, China has introduced various reforms gradually. As usual, China implements its 'share issue privatisation" in stages. In the late 1990s, wishing to compete with foreign rivals, the government only sold off small-sized state-owned firms and kept in state hands firms with a critical economic mass comparable with the Japanese keiretsu or the Korean

\footnotetext{
1 "Share issue privatisation' adopted by China is considered as a gradual approach, as opposed to the more radical 'asset privatization' carried out in the Eastern European economies.
} 
chaebol. As privatization deepens, the authorities still maintain their major presence and controlling stakes in strategic and pillar industries, such as chemical, steel, utilities and transport equipment. These strategic industries have high state ownership and are big in size. Wei and Varela (2003) and $\mathrm{Ng}$ et al. (2009) confirm that firm size is one of the main determinants of China's state ownership and the state exerts control over large firms for employment and social welfare reasons. As argued by Bolton and von Thadden (1998) and Brounen et al. (2009) that high concentration of share ownership by nonretail investors, such as blockholders, company insiders and institutional investors, reduces the liquidity of a stock, the shares owned by the Chinese government are illiquid. Before the non-tradable share reform in 2005, state-owned shares were prohibited from being traded in the market. Even though all shares have become tradable since the reform, the state has hardly sold off its stakes in a large scale in the firms of strategic importance, making no significant difference to the liquidity of shares in state hands. It appears that firm characteristics such as size, concentration of ownership and liquidity are related to residual state ownership in China.

\subsection{Non-linear relationship between residual state ownership and political interference}

The literature has established a relationship between privatisation and political interference, but the sign of the relationship depends on whether we chart it across fully- and partlyprivatised firms or among partly privatised firms. Perotti (1995) suggests that fully-privatised firms face higher political risk than partly-privatised firms. He shows theoretically that residual state ownership in a privatised firm can serve as a commitment device to mitigate political risk. With incomplete information about government's preferences, investors treat the stakes a government keeps in partly-privatised firms as a credible signal of its willingness not to interfere in the running of the businesses. Fully-privatised firms, on the other hand, are left prone to exposure to the risk of political interference. Hence, fully-privatised firms should be more risky than firms where governments keep residual stakes, and as such they 
should yield higher expected returns. Bortolotti and Faccio (2009) find evidence that partlyprivatised firms are more valuable than fully-privatised ones, but there is no empirical evidence to support Perotti (1995) that fully-privatised firms are more risky than partlyprivatised ones. On the other hand, the empirical literature on the development of emerging stock markets suggests a negative correlation between the risk of political interference and the progress of privatisation programmes in developing countries. That is, among partlyprivatised firms, political risk decreases as privatisation deepens. Perotti and van Oijen (2001) suggests that the actual implementation of privatisation programmes contributes to building investor confidence about political commitment to market-oriented reforms, hence progress in privatisation is positively correlated with improvements in perceived political risk. Bekaert and Harvey (2003) explain that successful privatisation of politically sensitive industries may convince investors to reduce the ex-ante perceived risk of government interference in investment decisions and expropriation of productive assets. Hence, among partly-privatised firms, it is expected that political interference decreases as privatisation deepens.

In their study on stock price informativeness, Ben-Nasr and Cosset (2014) find that stock price informativeness decreases under state ownership and suggest that higher state ownership is associated with higher post-privatisation political interference, and hence with lower transparency and lower firm-level stock price variation. Their result is robust across a variety of measures of state ownership, from percentage of state ownership to ultimate state ownership (i.e., states having at least $10 \%$ voting rights of privatised firms) or state ownership with control (i.e., governments owning more than $50 \%$ of the shares of privatised firms). The authors distinguish between the cases of control and revenue privatisation through the threshold of $50 \%$ state ownership. When it retains more than $50 \%$ of the shares of a privatised firm, the government intends to be involved in corporate decision-making rather 
than simply generate revenues through privatisation. The literature on the relationship between privatisation and corporate performance is also informative for our study. $\mathrm{Ng}$ et al. (2009) confirm that this relationship in China appears to be convex, suggesting benefits from either heavy privatisation or strong state control. While private owners are better motivated to monitor, discipline and reward their managers to improve firm performance, $\mathrm{Ng}$ et al. (2009) consider that government political support and business connections provided through state ownership are valuable and necessary too.

All these theoretical arguments and empirical evidence motivate us to control for political interference using residual state ownership in the assessment of stock market integration. Following the literature, we will deal with the non-linearity by stratifying the sample and interpreting our results in two separate contexts, between fully and partly privatised firms and among partly privatised firms. We have not seen much work on the relationship between residual state ownership and beta risk pricing or between level of political interference and degree of stock market integration. The most relevant study is Bekaert (1995), which finds that global factors account for a small fraction of expected returns in most markets and the emerging markets exhibit different degrees of integration with the US market. The most important de facto barriers to market integration are country-specific risk factors. On the basis of the literature and taking into account the ownership structure of the Chinese stocks, we hypothesise that decreasing state ownership will reduce investors' exposure to the

national risk factor, hence the barriers to stock market integration. Validation of this hypothesis will encourage emerging markets to pursue a vigorous privatisation programme in order to reap the benefits of stock market integration.

\section{Empirical framework and methodology}


This empirical study is carried out within the theoretical framework of Jorion and Schwartz (1986) using the procedure developed by Li (2013). Jorion and Schwartz (1986) propose to augment the international CAPM with an orthogonal national excess return or the domestic CAPM with an orthogonal global excess return and derive the following test equations.

$R_{i t}=\gamma_{0}\left(1-\beta_{i}^{G}\right)+\gamma_{2} \beta_{i}^{N-G}+\beta_{i}^{G} R_{G t}+\beta_{i}^{N-G} \omega_{(N-G) t}+e_{i t}^{G}$

and

$R_{i t}=\delta_{0}\left(1-\beta_{i}^{N}\right)+\delta_{2} \beta_{i}^{G-N}+\beta_{i}^{N} R_{N t}+\beta_{i}^{G-N} \omega_{(G-N) t}+e_{i t}^{N}$

where $\mathrm{R}$ is the excess return of a portfolio. For each portfolio, $\beta^{\mathrm{G}}$ and $\beta^{\mathrm{N}}$ are systematic risks relative to the global and national market returns, $R_{G}$ and $R_{N}$, respectively. They are also known as the unorthogonal systematic risks, as opposed to the terms, $\beta^{N-G}$ and $\beta^{G-N}$, that are orthogonal systematic risks and represent systematic risks relative to the independent national and global markets. Empirical counterparts to these independent market returns, $\omega_{\mathrm{N}-\mathrm{G}}$ and $\omega_{\mathrm{G}-\mathrm{N}}$, are constructed by a least squares decomposition of an OLS regression of the national (/global) market return upon the global (/national) return.

We follow Li (2013) and modify Eq. (1) as follows to permit time-varying systematic risks, in line with the considerable literature that beta risks are not constant over time.

$$
\begin{gathered}
R_{t}=\mu_{t}+\beta_{t}^{G} R_{G t}+\beta_{t}^{N-G} \omega_{(N-G) t}+e_{t}^{G} \\
\mu_{t}=\mu_{t-1}+\varepsilon_{t} \\
\beta_{t}^{G}=\beta_{t-1}^{G}+\eta_{t} \\
\beta_{t}^{N-G}=\beta_{t-1}^{N-G}+v_{t}
\end{gathered}
$$

That is, we use $\mu$ to represent the intercept of Eq. (1) and allow the parameters, $\mu, \beta^{G}$ and $\beta^{N-}$ ${ }^{G}$, to vary over time by following independent random walks. Although it seems simplistic to generate the time-varying coefficients via the random walk models, the random walk 
approach avoids the mis-specification error that disadvantages the alternative approach, the instrumental variable approach. Eqs. (2.1) to (2.3), therefore, constitute the transition equations of a state space model with Eq. (2) being the measurement equation. Similarly, a set of transition equations, Eqs. (2.1') to (2.3'), and a measurement equation, Eq. (2'), can be derived for Eq. (1'). The Kalman smoothing technique can then be used to estimate the timevarying parameters in these two state space models.

The restrictions, $\mu_{t}=\gamma_{0}\left(1-\beta_{t}^{G}\right)+\gamma_{2} \beta_{t}^{N-G}$ and $\mu_{t}=\delta_{0}\left(1-\beta_{t}^{N}\right)+\delta_{2} \beta_{t}^{G-N}$, are now testable implications of the asset pricing theory that underpins Eqs. (1) and (1'). That is, we can test for integration versus segmentation, respectively, in the following two-factor asset pricing models:

$\mu_{t}^{G}=\gamma_{0}\left(1-\beta_{t}^{G}\right)+\gamma_{2} \beta_{t}^{N-G}+\xi_{t}^{G}$

and

$\mu_{t}^{N}=\delta_{0}\left(1-\beta_{t}^{N}\right)+\delta_{2} \beta_{t}^{G-N}+\xi_{t}^{N}$

If $\gamma_{2}=0$ in Eq. (3), the global systematic risk is the only influencing factor in asset pricing, favouring the hypothesis of integration with the global market. When $\boldsymbol{\delta}_{2}=0$ in Eq. (3'), the national systematic risk is the only determinant of asset pricing, supporting the hypothesis of segmentation. In the context of the Chinese stock market, we expect that $\gamma_{2}=0$ holds most likely in the portfolio of the firms that have been privatised to the highest extent or have been fully privatised. On the other hand, we do not expect that $\delta_{2}=0$ holds in the Chinese stock market due to its strong trade links with the rest of the world. The rejection of $\gamma_{2}=0$ and $\delta_{2}=0$ in favour of $\gamma_{2}>0$ and $\delta_{2}>0$ will expose the portfolios to both the global and national systematic risks, providing evidence of partial integration with the global market. 
Since China experienced various reforms and changes during the sample period, we will use the Bai-Perron algorithm (2003) to detect structural changes in the relationships in Eqs. (3) and ( $\left.3^{\prime}\right)$. Once the break points are identified, we will introduce $\mathrm{m}$ indicators, $\mathrm{D}_{\mathrm{it}}$, taking a value of unity since the break point $t$ and zero otherwise, in Eqs. (3) and (3') as follows:

$\mu_{t}^{G}=\gamma_{0}\left(1-\beta_{t}^{G}\right)+\gamma_{2} \beta_{t}^{N-G}+\sum_{i=1}^{m} c_{i \gamma 0} D_{i t}\left(1-\beta_{t}^{G}\right)+\sum_{i=1}^{m} c_{i \gamma 2} D_{i t} \beta_{t}^{N-G}+\xi_{t}^{G}$

and

$\mu_{t}^{N}=\delta_{0}\left(1-\beta_{t}^{N}\right)+\delta_{2} \beta_{t}^{G-N}+\sum_{i=1}^{m} c_{i \delta 0} D_{i t}\left(1-\beta_{t}^{N}\right)+\sum_{i=1}^{m} c_{i \delta 2} D_{i t} \beta_{t}^{G-N}+\xi_{t}^{N}$

where $\mathrm{m}$ is the number of break points that are common to all or the majority of the portfolios under the principle of parsimony. The inclusion of the break points can be justified by the Wald tests of $c_{i \gamma j}=0$ or $c_{i \delta j}=0$ with $\mathrm{i}=1, \ldots$ and $\mathrm{m}$ and $\mathrm{j}=0$ (for the unorthogonal systematic risks) and 2 (for the orthogonal systematic risks). The changes in portfolios' asset pricing mechanisms can be examined by individually testing for hypotheses relating to the coefficients of the interaction terms, $c_{i \gamma j}$ and $c_{i \delta j}$. A hypothesis of integration since and/or up to break $\mathrm{i}$ is represented by $\gamma_{2}+\sum_{i=1}^{m} c_{i \gamma 2}=0$ in Eq. (4), whilst the segmentation hypothesis is $\delta_{2}+\sum_{i=1}^{m} c_{i \delta 2}=0$ in Eq. (4').

As an alternative, we will estimate Eqs. (3) and (3') parsimoniously by controlling for all structural changes endogenously using the Markov two-state regime-switching approach. This approach allows a hypothetical regularity in stock market behaviour by categorising the changes into two groups, one resulting in high volatility and the other low volatility, as follows. 
$\mu_{t}^{G}=\gamma_{0, s_{t}}\left(1-\beta_{t}^{G}\right)+\gamma_{2, s_{t}} \beta_{t}^{N-G}+\xi_{t}^{G}$

and

$\mu_{t}^{N}=\delta_{0, s_{t}}\left(1-\beta_{t}^{N}\right)+\delta_{2, s_{t}} \beta_{t}^{G-N}+\xi_{t}^{N}$

where $\operatorname{var}\left(\xi_{t}^{G}\right)=\sigma_{G s_{t}}^{2}$ and $\operatorname{var}\left(\xi_{t}^{N}\right)=\sigma_{N s_{t}}^{2}$ with $s_{t} \in[1,2]$. As usual, the parameters in the system will be estimated simultaneously using a maximum likelihood approach. We will further generate $\left\{p_{1 t}\right\}$, the probability for regime 1 being in force at each point in time, using the following recursive representation of Gray (1996).

$\boldsymbol{p}_{1 t}=(1-Q)\left[\frac{\boldsymbol{g}_{2 t-1}\left(1-\boldsymbol{p}_{1 t-1}\right)}{\boldsymbol{g}_{1 t-1} \boldsymbol{p}_{t t-1}+\boldsymbol{g}_{2 t-1}\left(1-\boldsymbol{p}_{1 t-1}\right)}\right]+\boldsymbol{P}\left[\frac{\boldsymbol{g}_{1 t-1} \boldsymbol{p}_{1 t-1}}{\boldsymbol{g}_{t t-1} \boldsymbol{p}_{t t-1}+\boldsymbol{g}_{2 t-1}\left(1-\boldsymbol{p}_{1 t-1}\right)}\right]$

where $P=\operatorname{Pr}\left(S_{t}=1 \mid S_{t-1}=1\right)$ and $Q=\operatorname{Pr}\left(S_{t}=2 \mid S_{t-1}=2\right)$ are the probabilities to stay in regimes 1 and 2 at time $\mathrm{t}$, respectively, and $g_{1 \mathrm{t}-1}=f\left(\mu_{\mathrm{t}-1} \mid \mathrm{S}_{\mathrm{t}-1}=1\right)$ and $g_{2 \mathrm{t}-1}=f\left(\mu_{\mathrm{t}-1} \mid \mathrm{S}_{\mathrm{t}-1}=2\right)$ are the likelihood of being in regime $\mathrm{j}$ at time $\mathrm{t}-1$ conditional on being in state $\mathrm{j}$ and information of time $\mathrm{t}-1$. We can plot $p_{t}$ against time for each portfolio and contrast between the regime-switching points identified by the recursive representation of Gray (1996) and the structural breaks identified by the Bai-Perron algorithm (2003).

\section{Portfolio compilation and preliminary analysis}

Data for this study are monthly time series from January 2000 until December 2011, representing possibly the longest period with the biggest sample size of firms in which the government keeps stakes. We retrieve data on the number of total shares and the number of state-owned shares for 2663 firms during 2000-2011 from the website of Chinese Security Market and Accounting Research (CSMAR). Among these 2663 firms, 54 firms have zero state ownership throughout the sample period and 408 firms have been fully privatised in the 
period under study and remained privately owned until at least 2014. In the remaining firms, by removing firms that have missing state ownership data or have zero state ownership in any year from 2000 to 2011, we retain 182 firms that have a complete series of non-zero state ownership during 2000-2011. We calculate percentages of state ownership for these 182 firms and sort these firms by their percentages of state ownership from the smallest to the largest each year. We then stratify the sample and calculate yearly average percentages of state ownership for the bottom, middle and top $25 \%$ of the firms in the state ownership distribution over the sample period of $2000-2011^{2}$.

Figure 1 plots the average percentages of state ownership for the bottom (decreasing from $17.65 \%$ to $2.33 \%$ over time), middle ( $47.6 \%$ to $24.1 \%$ ) and upper ( $69.8 \%$ to $59.3 \%$ ) quartiles during 2000-2011. The government is expected to have control rights in the firms falling in the upper quartile of the distribution. It is observed that the average percentages of residual state ownership decrease, albeit less sharply in the upper quartile, over time. The major turning point appears to be in 2005 when China started the non-tradable share reform. These features are consistent with the Chinese government's aims of reforming the ownership structure of stated-owned enterprises: maintaining its controlling stakes in the strategic and pillar industries, while permitting competition in non-strategic industries of consumer goods or services.

[Figure 1 is about here.]

We then retrieve from CSMAR the monthly closing share prices and market values for the 54 firms that have never been owned by the state, 408 firms that have been fully privatised and 182 firms that are still partly owned by the state during the period of December 1999-

\footnotetext{
${ }^{2}$ Given the relatively small sample size, we use quartiles instead of quintiles to ensure sufficient data points in each group and the middle $25 \%$ of the distribution to distinguish the average state ownership from those in the bottom and upper quartiles.
} 
December 2011. The series of the closing prices and market values are complete for the 54 firms that have never been owned by the state. However, only 198 out of the 408 fullyprivatised firms have the complete series of closing prices and market values. Some of the 182 partly-privatised firms do not have complete series of closing prices either. Omitting the firms with missing data, we manage to retain at least 33 and up to 45 stocks in the bottom quartile of the state ownership distribution, and 36 to 45 stocks in both the middle and upper quartiles during the period. We then calculate the monthly market value-weighted average prices for the five portfolios, namely the shares of the firms that have never been owned by the state (denoted by ZERO thereafter), the shares of the firms that have been fully privatised (FULPRI), and the shares of the firms whose residual state ownership fall, respectively, in the bottom (BOTQUAR), middle (MIDQUAR) and upper (UPPQUAR) quartiles of the distribution from January 2000 to December 2011. Figure 2 plots the market value-weighted average prices of the portfolios of ZERO, FULPRI and MIDQUAR during 2000-2011. It is noted that the average prices of the three portfolios moved together before 2009. These average stock prices continued to increase through 2007 even when the global financial crisis started. These average stock prices did not start to fall until the beginning of 2008 . By the end of 2008 the average prices have only fallen to the lowest level of 2007. Since 2009, the average prices of these portfolios have started to diverge, with the average share price of the firms with a medium level of residual state ownership becoming the highest in 2010 and 2011.

[Figure 2 is about here.]

The variable of interest in this study is the excess returns of the five portfolios. We generate the excess returns as follows. We convert the market value-weighted average prices of the five portfolios in Chinese Yuan to those in the US dollar, using the monthly exchange rates retrieved from the Federal Reserve website. We then calculate realised returns for the five 
portfolios by taking the first differences of natural logarithm of these average prices during December 1999 - December 2011. The excess returns are the differences between the realised returns and the risk-free rates obtained from CSMAR. We use the Chinese A-share market index in the US dollar compiled by Datastream to represent the Chinese national market portfolio, as this index covers the vast majority of stock listings on the stock exchanges in Shanghai and Shenzhen. The excess return of the national market is hence the difference between the realised return of the national market and the risk-free rate from the CSMAR website. The global market portfolio is represented by the MSCI world all country index and its risk-free rate is from Kenneth French's website ${ }^{3}$. Table 1 reports the summary statistics for the excess returns of the five portfolios in contrast with those of the national and the global stock markets.

[Table 1 is about here.]

Table 1 shows that all portfolios, including the national and global market portfolios, have performed poorly in the sample period. Given the stronger rate of return on the Chinese riskfree investment, the Chinese portfolios may not have performed much worse than the global market portfolio. As expected, volatility, as measured by standard deviations, of the Chinese excess returns is greater than that of the global excess return. Within the Chinese portfolios, the excess return of FULPRI is the least volatile. Among the three portfolios of the partlyprivatised firms, however, volatility decreases as state control increases. The statistics support our effort to distinguish between part- and full-privatisation when asserting a relationship between total risk and residual state ownership.

\section{Empirical results}

\subsection{Sensitivities to the national and global factors}

\footnotetext{
${ }^{3} \mathrm{http}: / /$ mba.tuck.dartmouth.edu/pages/faculty/ken.french/data_library.html.
} 
We first estimate the constant-coefficient version of Eqs. (2) and (2') by OLS to derive the benchmark time-invariant unorthogonal and orthogonal systematic risks: $\beta^{G}, \beta^{N-G}, \beta^{N}$ and $\beta^{G-N}$ for the five portfolios under study. For all portfolios, as reported in Table 2, both the unorthognoal and orthogonal national systematic risks, $\beta^{N}$ and $\beta^{N-G}$, are individually statistically significant and their global counterparts, $\beta^{G}$ and $\beta^{G-N}$, are not, suggesting that the excess returns of the Chinese portfolios are only sensitive to the excess return of the national market. Moreover, according to the Wald $\operatorname{tests}^{4}$ on the coefficients, the unorthogonal and orthogonal national systematic risks are not statistically different from each other within portfolios. Between portfolios, the Chinese stocks are equally sensitive to the national factor, as the magnitudes of the national systematic risks, $\beta^{N}$ and $\beta^{N-G}$, are respectively confirmed by the Wald tests not to be statistically different from one another. It seems that time-invariant sensitivities to the national and global systematic risks are, respectively, homogenous across portfolios.

[Table 2 is about here.]

We then estimate Eqs. (2) and (2') using the Kalman smoothing algorithm to obtain timevarying unorthogonal and orthogonal systematic risks. We remove the first eighteen estimates from the resulting series to avoid the instability and extreme values that are typical in the initialisation period of the smoothing algorithm and plot them against time in Figure 3. These figures show that all of the national and global systematic risks vary over time and that the national systematic risks, either unorthogonal or orthogonal, are greater than their global counterparts in all cases. The orthogonal national systematic risks in Panel A of Figure 3 appear to be equal in magnitude to their unorthogonal counterparts in Panel B, similar to the results of the Wald tests on the equality of the time-invariant coefficients in Eqs. (2) and (2'). However, even the orthogonal global systematic risks in Panel B are not uniformly zero as

\footnotetext{
${ }^{4}$ The Wald test results about coefficients here and thereafter are available on request.
} 
suggested by the constant-beta approach. An upward trend can be observed in the orthogonal global systematic risks for most of the portfolios during 2004 and 2008. In the case of FULPRI, the orthogonal global systematic risk started to rise in 2004 at the earliest and the magnitude of the time-varying orthogonal global systematic risk was the highest, possibly suggesting that the shares of the fully-privatised firms are the most sensitive to the global factor.

Overall, according to the exploratory analyses, the domestic factor is always relevant to the pricing of the Chinese securities regardless of their extent of privatisation, while the global factor becomes relevant, especially for the determination of the return of the shares of fullyprivatised firms, in the latter part of the period under study. We expect that the disparity in the sensitivities of the portfolios to the excess returns of the national and global markets will result in different risk pricing of the fully- and partly-privatised firms.

[Figure 3 is about here.]

\subsection{Risk prices in relation to residual state ownership}

In order to formally examine asset-pricing mechanism in relation to residual state ownership, we firstly substitute the time-varying coefficients of Eqs. (2) and (2') to Eqs. (3) and (3') and estimate the benchmark prices of the global and national systematic risks for the Chinese portfolios during July 2001 and December 2011. The results are reported in Table 3. Although they are not sensitive or are less sensitive to the global excess return in Eqs. (2) and $\left(2^{\prime}\right)$ in the previous section, all the Chinese portfolios expose positively to both unorthogonal ${ }^{5}$ and orthogonal global systematic risks in Eqs. (3) and (3'). The positive pricing of the orthogonal global systematic risks in Eq. (3') supports our expectation that the hypothesis of

\footnotetext{
${ }^{5}$ The coefficients of $\left(1-\beta_{t}^{G}\right)$ and $\left(1-\beta_{t}^{N}\right), \gamma_{0}$ and $\delta_{0}$, must be negative in order for the unorthogonal global and national systematic risks to be positively priced respectively.
} 
segmentation is rejected in the Chinese stock market due to its strong trade links with the rest of the world. Three of the five portfolios, namely FULPRI, MIDQUAR and UPPQUAR, further reject the null hypothesis of integration in favour of positive exposure to the orthogonal national systematic risk in Eq. (3). These three portfolios, therefore, expose to both the global and national systematic risks and they consistently price the orthogonal global systematic risk more than the orthogonal national systematic risk. The Wald tests on the coefficients of the orthogonal global and national systematic risks in Eqs. (3) and (3') confirm that the two-beta CAPM is preferred to a pure domestic CAPM in these cases. Given that the results of the panel's fixed-effect model in Eq. (3) also suggest that both the global and national systematic risks are statistically significant in determining the returns of the Chinese portfolios, we conclude that the Chinese stock market is mainly partially integrated with the global market.

Although partial integration is evident in the portfolios of FULPRI, MIDQUAR and UPPQUAR, risk pricing by BOTQUAR and ZERO suggests the alternatives of partial integration respectively. In the case of BOTQUAR, the null hypothesis of integration cannot be rejected, while the null hypothesis of segmentation is rejected, leaving the global systematic risk as the only factor in influencing BOTQUAR's asset pricing. Hence BOTQUAR meets the condition of complete integration with the global market. Although the null hypothesis of integration is rejected, ZERO exposes negatively to the orthogonal national systematic risk, suggesting that the investors in the firms that have never been owned by the state discount the national risk in the sample period.

[Table 3 is about here.]

However, as reported by Table 4, using the Bai-Perron algorithm (Bai and Perron, 2003), we detect a range of 2 to 4 structural breaks, suggesting 3 to 5 regimes over time, in the 
relationships of Eqs. (3) and (3') across the five portfolios under study. Table 4 further reports that the breaks have occurred at different time points between Eqs. (3) and (3') even within portfolios. Because the location and number of the change points are not uniform within or between portfolios, we do not attempt to partition the sample period or estimate Eqs. (3) and (3') for the multiple non-matching sub-periods. Instead, we will estimate them parsimoniously, in order to obtain results general to the portfolios, by controlling for the most common breaks exogenously using a dummy variable approach as in Eqs. (4) and (4') or controlling for all breaks endogenously using the Markov regime-switching technique as in Eqs. (5) and (5').

[Table 4 is about here.]

\subsection{1. when structural changes are exogenously controlled for}

It is noted in Table 4 that all the portfolios experience a structural break at May 2004, around the time when the Chinese authorities implemented various measures to improve corporate governance of the listed companies. This is confirmed by the observation in Figure 3 that the global and national systematic risks have started to rise more or less since May 2004. Since the break point at May 2004, China has also implemented the non-tradable share reform. It is claimed that most of the non-tradable shares have become tradable by the end of 2007 . The second most common breaks, July 2008 for FULPRI and UPPQUAR and February 2009 for ZERO, BOTQUAR and MIDQUAR, correspond to the period when the global systematic risks fluctuate greatly in Figure 3. Note that July 2008 falls towards the latter part of the recent global financial crisis during August 2007 and March 2009, while February 2009 is very close to the end of the crisis. These two breaks capture the Chinese situations at the time well: the Chinese economy did not suffer from any major adverse effect of the global financial crisis until the crisis began to push the US and Europe into recession, reducing their 
imports from the emerging economies including China. Hence these second most common break points signal the start of a sub-period of economic recession in the world. In this section, we control for the most common breaks at May 2004 and February 2009, when estimating Eqs. (4) and (4') by a panel data regression. When estimating Eqs. (4) and (4') individually for the portfolios, we control for the two breaks, May 2004 and July 2008 or February 2009, as identified by the Bai-Perron algorithm. The results are reported in Table 5 . Note that the inclusion of the two break points is justified in all cases by the Wald tests of the null hypotheses of $c_{i \gamma j}=0$ and $c_{i \delta j}=0$ with $\mathrm{i}=1$ and 2 and $\mathrm{j}=0$ and 2 .

[Table 5 is about here.]

The estimates of the panel's fixed-effects model in Table 5 seem to support our conclusion in section 5.2 that the Chinese market is mainly partially integrated with the global market. The null hypotheses of integration and segmentation can be rejected, respectively, in favour of positive exposures to the orthogonal national and global systematic risks $\left(\gamma_{2}>0\right.$ and $\left.\delta_{2}>0\right)$ in the sub-period from July 2001 to April 2004. Since the break point of May 2004, the exposure to the orthogonal national systematic risk has increased and the exposure to the orthogonal global systematic risk has decreased. While that of the orthogonal global systematic risk is slightly lower, the price of the orthogonal national systematic risk is confirmed by the Wald test to be greater in the sub-period from May 2004 to January 2009 than the sub-period pre-May 2004. Moreover, the null hypotheses of integration and segmentation are still respectively rejected in favour of their alternatives $\left(\gamma_{2}+c_{1 \gamma 2}>0\right.$ and $\delta_{2}+c_{1 \delta 2}>0$ ), suggesting that the Chinese portfolios expose to both the national and global systematic risks during May 2004 and January 2009. In the subsequent sub-period following 
the break point of February 2009, the exposures to the unorthogonal ${ }^{6}$ and orthogonal national and global systematic risks have decreased. The decreases in the exposures to the orthogonal systematic risks have led to negative pricing of both the orthogonal national and global systematic risks $\left(\gamma_{2}+c_{1 \gamma 2}+c_{2 \gamma^{2}}<0\right.$ and $\left.\delta_{2}+c_{1 \delta 2}+c_{2 \delta 2}<0\right)$. It seems that the investors in the Chinese stock market are unwilling to pay any premium to hedge against national or global downturns during February 2009 and December 2011, when the world economy went into recession.

The results of Eqs. (4) and (4') for the individual portfolios reveal diverse risk pricing across portfolios and over time. In the period up to April 2004, the firms that have never been owned by the state (ZERO) positively price the orthogonal national systematic risk, while the firms that have been fully privatised (FULPRI) do so negatively. As a contrast, the firms that are still partly owned by the state, e.g., BOTQUAR, MIDQUAR and UPPQUAR, do not price the orthogonal national systematic risk, possibly because these firms have no incentive to price the national market risk in view of the government's guarantee on their finance. It seems that the Chinese stock market is more evidently integrated with the global market in this sub-period pre-April 2004. The estimates of Eq. (4') also suggest a strong influence of the global risk factor on the pricing of the portfolios in this sub-period. The strongest exposure to the orthogonal global risk factor is identified by the Wald tests to be FULPRI, consistent with the graphical observation in section 5.1 that FULPRI is the most sensitive to the global market excess return. In line with the theory of risk aversion that investment in the most risky or sensitive stock is rewarded most highly, the investors of the fully-privatised firms pay the highest premium to hedge against the global downturns.

\footnotetext{
${ }^{6}$ The coefficients of $D_{i t}\left(1-\beta_{t}^{G}\right)$ and $D_{i t}\left(1-\beta_{t}^{N}\right)$ in Eqs. (4) and (4'), $\mathrm{c}_{\mathrm{i} \gamma 0}$ and $\mathrm{c}_{\mathrm{i} \delta 0}$, must be negative for the changes in the prices of the unorthogonal risks to be positive.
} 
The break point at May 2004 has impacted the exposures almost consistently across portfolios. Specifically, the exposure to the orthogonal national systematic risk increases in all portfolios except ZERO and there is no change to the exposure to the orthogonal global systematic risk in all but UPPQUAR in the sub-period following May 2004. Consequently, the null hypotheses of integration and segmentation can be rejected, respectively, in favour of positive exposures to the orthogonal national and global risks across all portfolios, including those of the shares of the partly-privatised firms. Given the positive pricing of both the global and national systematic risks by all of the portfolios in the sub-period following May 2004, the Chinese stock market is partially integrated with the global market, consistent with the result of the panel data regression in the same sub-period. The measures for improving corporate governance since May 2004 may have cancelled out the effect of the government's financial guarantee for the partly-privatised firms, prompting these firms to expose additionally to the national systematic risk. Similar to the impacts of the break point of February 2009 observed in the panel data regression, the exposures to both the orthogonal national and global systematic risks have decreased in all portfolios since July 2008 or February 2009. Consequently, there is no evidence of complete or partial integration in the third sub-period. In the case of ZERO, furthermore, neither the null hypothesis of integration nor that of segmentation is rejected, leading to contradictory results between Eqs. (4) and (4'). In the case of MIDQUAR, market segmentation is confirmed in both Eqs. (4) and (4').

Overall, the results of Eq. (4') in Table 5 are mostly consistent with those reported in Table 3, supporting our expectation that the hypothesis of segmentation is rejected in the Chinese stock market due to China's strong trade links with the rest of the world. The Chinese portfolios have consistently priced the orthogonal global risk more highly than the orthogonal national risk. The estimates of Eq. (4) in Table 5, on the other hand, suggest different pricing of the national systematic risk between partly- and fully-privatised firms over the sub- 
periods. Negative pricing of the systematic risks is confined to the sub-period post-July 2008 or February 2009 when the world economy went into recession. It seems that investors are not rewarded for risk taking in any of the Chinese stocks during the economic recession.

\subsection{2 when structural changes are endogenously controlled for}

In this section, we use the Markov two-state regime-switching approach to characterise the potential structural breaks in Eqs. (3) and (3') as a consequence of occasional transition between two regimes, a high-volatility state and a low-volatility state as in Eqs. (5) and (5'). The estimated results of Eqs. (5) and (5') for the period of July 2001 to December 2011 are reported in Tables 6 and 7 respectively. The regimes can be distinguished by the standard deviations of the regression residuals, $\sigma_{s_{t}}$. According to these volatility measures on Tables 6 and 7, regimes 1 and 2 are the low-volatility and high-volatility states respectively. There is noticeable persistence in both states for all the portfolios since the probabilities of staying in the existing states, $\mathrm{P}(1,1)$ and $1-\mathrm{P}(1,2)$, are high. The persistence in both states results in the formation of the regimes in blocks over time as shown in Figure 4, where we plot the smoothed probabilities of volatility regimes generated by the recursive representation Eq. (6) of Gray (1996) for Eqs. (5) and (5'). Consistent with Figure 4, furthermore, the regime classification measure (RCM) takes values close to its lower limit, suggesting that our estimated two-state regime-switching model is able to distinctly classify the two alternative modes of behaviour for the Chinese portfolios. Although the portfolios hardly switch regimes at the most common break point of May 2004 as identified by the Bai-Perron algorithm (2003), most of the Chinese portfolios change their behaviour considerably at the break point of July 2008 or February 2009 by switching their states. It is not surprising that the economic recession period following the end of the recent global financial crisis is categorised as a high-volatility period in the Chinese data by the Markov regime-switching technique, given 
that the market value-weighted average share prices do appear to be more volatile in the period post-March 2009 than the period pre-August 2007 in Figure 2.

[Tables 6 and 7 are about here.]

[Figure 4 is about here.]

Using the two-state regime-switching technique, we firstly observe distinct risk prices across portfolios, as reported in Tables 6 and 7. In the case of BOTQUAR, the null hypothesis of integration $\left(\gamma_{21}=0\right.$ or $\left.\gamma_{22}=0\right)$ cannot be rejected in either low- or high-volatility periods, while the null hypotheses of segmentation $\left(\delta_{21}=0\right.$ and $\left.\delta_{22}=0\right)$ are rejected in both periods. These results support the conclusion from Table 3 that the firms that fall in the bottom quartile of residual state ownership distribution are fully integrated with the global market in the whole sample period. In the cases of ZERO and UPPQUAR, on the other hand, the null hypothesis of integration is rejected in favour of negative pricing of the orthogonal national systematic risk $\left(\gamma_{21}<0\right.$ and $\left.\gamma_{22}<0\right)$ in both low- and high-volatility periods. Note that Figure 4 shows that, in the case of UPPQUAR, the high-volatility period overlaps with the majority of the sub-period since July 2008. During this overlapped period, UPPQUAR negatively prices the national systematic risk, as detected by both the dummy variable approach and the regime-switching approach.

The remaining two portfolios' distinct risk prices in the low- and high-volatility periods appear to suggest that the Chinese stock market strengthens its integration with the global market in the high-volatility periods. For example, in the case of FULPRI, the null hypothesis of integration (in Table 6) is rejected in favour of positive exposure to the orthogonal national systematic risk in the low-volatility periods. But in the high-volatility periods, the null hypothesis of integration is not rejected, leaving the global systematic risk as the only 
determinant in the pricing of FULPRI. Although it negatively prices the orthogonal national systematic risk in the low-volatility periods, MIDQUAR does not expose to the orthogonal national systematic risk in the high-volatility periods. Given that the null hypothesis of segmentation (in Table 7) is rejected additionally, FULPRI and MIDQUAR are fully integrated with the global market in the high-volatility periods. However, in both cases, part of their high-volatility regimes overlaps the recent global financial crisis during August 2007 and March 2009. It is likely that the stronger integration with the global market has arisen from an increased propensity to hedge the global risk in the crisis, as suggested by Vermeulen (2013).

Overall, the international influence on the Chinese asset pricing is stronger in the highvolatility periods than in the low-volatility periods. Across portfolios, the Wald tests confirm that FULPRI and BOTQUAR price the orthogonal global systematic risk equally most highly in the high-volatility periods. However, the fully-privatised firms expose to the national systematic risk additionally, while the firms that fall in the bottom quartile of the residual state ownership distribution do not. Hence, the fully-privatised firms are no more integrated with the global market than the partly-privatised firms. Given that we cannot reject the null hypothesis of integration for BOTQUAR in any of the periods and for MIDQUAR only in the high-volatility periods, while rejecting it for UPPQUAR in all periods, we can conclude that the strength of integration with the global market is inversely related to the extent of residual state ownership among the partly-privatised firms. In the line of $\mathrm{Ng}$ et al. (2009), our results suggest that political support and connections through state ownership may be necessary for emerging economies to achieve integration with the global market.

\section{Conclusions}


This paper investigates the risk pricing by portfolios across China's state ownership distribution within the well-developed CAPM framework. The unique portfolios we compiled capture the institutional characteristics better and are therefore more appropriate for studies on asset pricing of emerging stock markets. Firstly, through anchoring our analysis to the unique portfolios, we successfully control for the potential risks, such as political interference and liquidity, associated with state ownership in the two-beta asset-pricing model and obtain empirical results that are mostly consistent with the theory of risk aversion, as opposed to the negative risk pricing often reported in the literature on emerging markets. Secondly, by contrasting pricing of the national and global systematic risks between the fully- and partlyprivatised firms and among the partly-privatised firms, we deduce a non-linear relationship between stock market integration and state ownership that is missing in the literature but is needed for the policy-making purposes.

We find that complete privatisation does not eliminate exposure to the national systematic risk. It is the firms in the bottom quartile of the state ownership distribution that are most likely not to price the national systematic risk. Within the partly-privatised firms, China's integration with the global stock market strengthens as residual state ownership decreases. These results suggest that emerging economies should pursue rigorous privatisation and yet their governments keep small stakes in privatised firms in order to ensure integration with the global market. In line with $\mathrm{Ng}$ et al. (2009), political support and business connections through state ownership may be necessary for achieving integration between emerging and global stock markets. However, from the experiences of developed economies, transparency with appropriate monitoring is the sufficient condition for firm performance, pointing to the need of research on stock market integration in relations to corporate governance in emerging economies. 
References

Ang, A., Bekaert, G., 2002. Regime switches in interest rates. Journal of Business and Economic Statistics 20(2), 163-182.

Bai, J., Perron, P., 2003. Computation and analysis of multiple structural change models. Journal of Applied Econometrics 18, 1-22.

Bekaert, G., 1995. Market Integration and Investment Barriers in Emerging Equity Markets. The World Bank Economic Review 9, 75-107.

Bekaert, G., Erb, C. B., Harvey, C. R., Viskanta, T. E., 1997. What matters for emerging market investment? Emerging Markets Quarterly 1 (2), 17-46

Bekaert, G., Harvey, C. R., 2003. Emerging markets finance. Journal of Empirical Finance 10, 3-55.

Ben-Nasr, H., Cosset, J., 2014. State ownership, political institutions and stock price informativeness: Evidence form privatisation. Journal of Corporate Finance 29, 179-199.

Bernstein, L., 1987. Liquidity, stock markets, and market makers. Financial Management 16, 54-62.

Bolton, P., von Thadden, E., 1998. Blocks, Liquidity, and Corporate Control. The Journal of Finance 53, 1-25.

Bortolotti, B., Faccio, M., 2009. Government control of privatised firms. Review of Financial Studies 22, 2907-2939

Brounen, D., Eichholtz, P., Ling, D., 2009. The liquidity of property shares: An international comparison. Real Estate Economics 37, 413-445.

Diamonte, R. L., Liew, J. M., Stevens, R. L., 1996. Political risk in emerging and developed markets. Financial Analysts Journal, 71-76.

Erb, C.B., Harvey C.R., Viskanta, T.E., 1996. Political risk, economic risk and financial risk. Finanical Analysts Journal 52, 29-46.

Fan, J., Wong, T., Zhang, T., 2014. Politically connected CEOs, corporate governance and the post-IPO performance of China's partially privatized firms. Journal of Applied Corporate Finance $26(3), 85-95$.

Gray, S., 1996. Modelling the conditional distribution of interest rates as a regime-switching process. Journal of Financial Economics 42, 27-62.

Haugen, R., 1999. 'The new finance: The case against efficient markets' $\left(2^{\text {nd }}\right.$ ed.) New Jersey: Prentice Hall, Inc.

Jorion, P., Schwartz, E., 1986. Integration vs segmentation in the Canadian Stock Market. Journal of Finance 41(3), 603-614.

Li, H., 2013. Integration versus segmentation in China's stock market: An analysis of timevarying beta risks. Journal of International Financial Markets, Institutions and Money 25, 88105. 
Mo, H., Wu, L., 2007. 'International capital asset pricing: Evidence from options'. Journal of Empirical Finance 14, 465-498.

Ng, A., Yuce, A., Chen, E., 2009. Determinants of state equity ownership and its effect on value/performance: China's privatised firms. Pacific-Basin Finance Journal 17, 413-443.

Omran, M., 2007. 'An analysis of the capital asset pricing model in the Egyptian stock market'. The Quarterly Review of Economics and Finance 46, 801-812.

Perotti, E. C., 1995. Credible privatization. American Economic Review 85, 847-859.

Perotti, E., Van Oijen, P., 2001. Privatization, Political Risk and Stock Market Development in Emerging Economies. Journal of International Money and Finance 20 (1), 43-69.

Vermeulen, R., 2013. International diversification during the financial crisis: A blessing for equity investors? Journal of International Money and Finance 35, 104-123.

Wang, Y., Di Iorio, A., 2007. Are the China-related stock markets segmented with both world and regional stock markets? Journal of International Financial Markets, Institutions and Money 17, 277-290.

Wei, Z., Varela, O., 2003. State equity ownership and firm market performance: Evidence from China's newly privatised firms. Global Finance Journal 14, 65-82 
Table 1 Summary statistics of the excess returns during 2000.1-2011.12

\begin{tabular}{|l|l|l|l|l|}
\hline & Mean & Maximum & Minimum & Standard Deviation \\
\hline ZERO & -2.71 & 29.07 & -35.45 & 9.84 \\
\hline FULPRI & -2.42 & 24.71 & -41.35 & 9.46 \\
\hline BOTQUAR & -2.68 & 33.32 & -36.63 & 10.45 \\
\hline MIDQUAR & -2.69 & 27.25 & -27.29 & 10.16 \\
\hline UPPQUAR & -2.32 & 25.84 & -39.21 & 9.72 \\
\hline NATIONAL & -2.13 & 20.95 & -32.30 & 8.61 \\
\hline GLOBAL & -0.24 & 17.42 & -17.81 & 5.51 \\
\hline CN rf rate & 2.51 & 4.14 & 1.98 & 0.64 \\
\hline US rf rate & 0.19 & 0.56 & 0 & 0.17 \\
\hline
\end{tabular}

Note: ZERO = portfolio of stocks of firms that have never been state owned FULPRI = portfolio of stocks of firms that have been fully privatised stocks BOTQUAR = portfolio of stocks of firms falling in the bottom quartile of the state ownership distribution MIDQUAR $=$ portfolios of stock of firms falling in the middle $25 \%$ of the state ownership distribution

UPPQUAR = portfolio of stocks of firms falling in the upper quartile of the state ownership distribution

NATIONAL $=$ the Chinese A-share market index

GLOBAL $=$ MSCI all country index

$\mathrm{CN}$ rf rate $=$ the Chinese risk-free rate of return

US rf rate $=$ the US risk-free rate of return 
Table 2 Estimates of Eqs. (2) and (2') by OLS during 2000.1-2011.12

\begin{tabular}{|c|c|c|c|c|c|c|c|c|}
\hline & Eq. (2) & & & & Eq. $\left(2^{\prime}\right)$ & & & \\
\hline & $\mu$ & $\beta^{G}$ & $\beta^{\mathrm{N}-\mathrm{G}}$ & $\begin{array}{l}\chi^{2} \\
\left(\beta^{N-G}=0\right)\end{array}$ & $\mu$ & $\beta^{N}$ & $\beta^{\mathrm{G}-\mathrm{N}}$ & $\begin{array}{l}\chi^{2} \\
\left(\beta^{\mathrm{G}-\mathrm{N}}=0\right)\end{array}$ \\
\hline ZERO & $\begin{array}{l}-2.693 * * * \\
(0.803)\end{array}$ & $\begin{array}{l}0.071 \\
(0.146)\end{array}$ & $\begin{array}{l}0.271 * * * \\
(0.096)\end{array}$ & $7.967 * * *$ & $\begin{array}{l}-2.141 * * \\
(0.827)\end{array}$ & $\begin{array}{l}0.267 * * * \\
(0.094)\end{array}$ & $\begin{array}{l}-0.025 \\
(0.150)\end{array}$ & 0.029 \\
\hline FULPRI & $\begin{array}{l}-2.373 * * * \\
(0.778)\end{array}$ & $\begin{array}{l}0.185 \\
(0.142)\end{array}$ & $\begin{array}{l}0.196^{* *} \\
(0.093)\end{array}$ & $4.442 * * *$ & $\begin{array}{l}-1.964 * * \\
(0.801)\end{array}$ & $\begin{array}{l}0.213 * * \\
(0.091)\end{array}$ & $\begin{array}{l}0.115 \\
(0.145)\end{array}$ & 0.630 \\
\hline BOTQUAR & $\begin{array}{l}-2.648 * * * \\
(0.859) \\
\end{array}$ & $\begin{array}{l}0.125 \\
(0.156)\end{array}$ & $\begin{array}{l}0.242 * * \\
(0.103)\end{array}$ & $5,542 * * *$ & $\begin{array}{l}-2.151 * * \\
(0.884)\end{array}$ & $\begin{array}{l}0.247 * * \\
(0.100)\end{array}$ & $\begin{array}{l}0.039 \\
(0.161)\end{array}$ & 0.058 \\
\hline MIDQUAR & $\begin{array}{l}-2.668 * * * \\
(0.835) \\
\end{array}$ & $\begin{array}{l}0.079 \\
(0.152)\end{array}$ & $\begin{array}{l}0.248 * * \\
(0.100)\end{array}$ & $6.192 * * *$ & $\begin{array}{l}-2.161 * * \\
(0.859)\end{array}$ & $\begin{array}{l}0.247 * * \\
(0.100) \\
\end{array}$ & $\begin{array}{l}-0.010 \\
(0.156) \\
\end{array}$ & 0.004 \\
\hline UPPQUAR & $\begin{array}{l}-2.286 * * * \\
(0.792)\end{array}$ & $\begin{array}{l}0.157 \\
(0.144)\end{array}$ & $\begin{array}{l}0.263 * * * \\
(0.095)\end{array}$ & $7.682 * * *$ & $\begin{array}{l}-1.745^{* *} \\
(0.816)\end{array}$ & $\begin{array}{l}0.272 * * * \\
(0.093)\end{array}$ & $\begin{array}{l}0.063 \\
(0.148)\end{array}$ & 0.182 \\
\hline
\end{tabular}

Note: This table reports estimates of equations:

(2) $\boldsymbol{R}_{t}=\mu+\beta^{G} \boldsymbol{R}_{G t}+\beta^{N-G} \omega_{(N-G) t}+\boldsymbol{e}_{t}$ where $\omega_{(N-G) t}=\boldsymbol{R}_{N t}+2.043-0.356 \boldsymbol{R}_{G t}$

$$
\text { s.e. } \quad(0.702) \quad(0.128)
$$

and

(2') $\boldsymbol{R}_{t}=\boldsymbol{\mu}+\boldsymbol{\beta}^{N} \boldsymbol{R}_{N t}+\boldsymbol{\beta}^{G-N} \omega_{(G-N) t}+\boldsymbol{e}_{t}$ where $\omega_{(G-N) t}=\boldsymbol{R}_{G t}-0.072-0.146 \boldsymbol{R}_{N t}$

$$
\text { s. e. } \quad(0.462) \quad(0.052)
$$

The heteroscedasticity-consistent (Eicker-White) standard errors are in brackets. $*, * *$ and $* * *$ represent levels of significance at $1 \%, 5 \%$ and $10 \%$ respectively. The $\chi^{2}$ critical value is 2.706 at one degree of freedom and $10 \%$ level of significance. 
Table 3 Estimates of Eqs. (3) and (3') by OLS during 2001.7-2011.12

\begin{tabular}{|c|c|c|c|c|c|c|}
\hline & \multicolumn{3}{|c|}{ Eq.(3) } & \multicolumn{3}{|c|}{ Eq. (3') } \\
\hline & $\gamma_{0}$ & $\gamma_{2}$ & $\chi^{2}\left(\gamma_{2}=0\right)$ & $\delta_{0}$ & $\delta_{2}$ & $\chi^{2}\left(\delta_{2}=0\right)$ \\
\hline PANEL & $\begin{array}{l}-4.040 * * * \\
(0.229)\end{array}$ & $\begin{array}{l}0.360 * \\
(0.198)\end{array}$ & $3.284^{*}$ & $\begin{array}{l}-1.840 * * * \\
(0.230)\end{array}$ & $\begin{array}{l}0.563 * * * \\
(0.149)\end{array}$ & $14.22 * * *$ \\
\hline ZERO & $\begin{array}{l}-3.553 * * * \\
(0.069)\end{array}$ & $\begin{array}{l}-0.518 * * \\
(0.279)\end{array}$ & $6.432 * *$ & $\begin{array}{l}-3.759 * * * \\
(0.069)\end{array}$ & $\begin{array}{l}1.247^{*} \\
(0.709)\end{array}$ & $3.095^{*}$ \\
\hline FULPRI & $\begin{array}{l}-3.937 * * * \\
(0.061)\end{array}$ & $\begin{array}{l}1.589 * * * \\
(0.142)\end{array}$ & $32.48 * * *$ & $\begin{array}{l}-3.829 * * * \\
(0.049)\end{array}$ & $\begin{array}{l}4.663 * * * \\
(0.318)\end{array}$ & $214.89 * * *$ \\
\hline BOTQUAR & $\begin{array}{l}-3.540^{* * * *} \\
(0.070)\end{array}$ & $\begin{array}{l}0.207 \\
(0.254)\end{array}$ & 0.664 & $\begin{array}{l}-3.557 * * * \\
(0.050)\end{array}$ & $\begin{array}{l}2.884 * * * \\
(0.423)\end{array}$ & $46.50 * * *$ \\
\hline MIDQUAR & $\begin{array}{l}-3.968 * * * \\
(0.087)\end{array}$ & $\begin{array}{l}1.737 * * * \\
(0.341)\end{array}$ & $25.95 * * *$ & $\begin{array}{l}-3.684 * * * \\
(0.065)\end{array}$ & $\begin{array}{l}4.352 * * * \\
(0.705)\end{array}$ & $38.14 * * *$ \\
\hline UPPQUAR & $\begin{array}{l}-3.445^{* * * *} \\
(0.056)\end{array}$ & $\begin{array}{l}0.903 * * * \\
(0.211)\end{array}$ & $18.24 * * *$ & $\begin{array}{l}-3.308 * * * \\
(0.043)\end{array}$ & $\begin{array}{l}3.416 * * * \\
(0.352)\end{array}$ & $94.10 * * *$ \\
\hline
\end{tabular}

Note: $\gamma_{0}$ and $\delta_{0}$ are, respectively, the coefficients of the unorthogonal global and national systematic risks, while $\gamma_{2}$ and $\delta_{2}$ are those of the orthogonal national and global systematic risks. The estimates for PANEL are from the fixed-effects model of a panel data regression. The standard errors are in brackets. $*, * *$ and $* * *$ represent levels of significance at $1 \%, 5 \%$ and $10 \%$ respectively. The $\chi^{2}$ critical value is 2.706 at one degree of freedom and $10 \%$ level of significance. 
Table 4 The Bai-Perron (2003) multiple change point analysis on Eqs. (3) and (3')

\begin{tabular}{lllll}
\hline \multirow{2}{*}{ Portfolio } & \multicolumn{2}{c}{ Eq. (3) } & Eq. (3') \\
\cline { 2 - 5 } & No. Breaks & Time points & No. Breaks & Time points \\
\hline ZERO & $2004: 05$ & 2 & $2004: 05$ \\
& $2007: 11$ & & $2007: 02$ \\
& $2009: 02$ & & $2002: 12$ \\
& 3 & $2003: 01$ & 3 & $2004: 05$ \\
& $2004: 05$ & & $2007: 10$ \\
\hline BULPRI & $2008: 07$ & & $2004: 05$ \\
& $2004: 05$ & 3 & $2007: 09$ \\
& $2009: 02$ & & $2008: 12$ \\
\hline MIDQUAR & 3 & $2004: 05$ & 3 & $2004: 05$ \\
& & $2007: 11$ & & $2009: 11$ \\
\hline UPPQUAR & $2009: 02$ & & $2005: 04$ \\
& 4 & $2002: 09$ & 3 & $2007: 09$ \\
& $2005: 04$ & & \\
\hline
\end{tabular}

Note: The Bai-Perron algorithm is applied to Eqs. (3) and (3') in the sample period of July 2001 and December 2011. The data points before July 2001 are omitted to avoid the typically unstable or extreme estimates of the beta risks in the initialisation period of the Kalman smoothing algorithm in Eqs. (2) and (2'). The number of break points is identified by using BIC statistics. 
Table 5 Estimates of Eqs. (4) and (4') by OLS and diagnostic tests of the breaks

\begin{tabular}{|c|c|c|c|c|c|c|}
\hline & PANEL & ZERO & FULPRI & BOTQUAR & MIDQUAR & UPPQUAR \\
\hline \multicolumn{7}{|l|}{ Eq. (4): } \\
\hline$\gamma_{0}$ & $\begin{array}{l}-2.946 * * * \\
(0.180)\end{array}$ & $\begin{array}{l}-3.787 * * * \\
(0.079)\end{array}$ & $\begin{array}{l}-4.021 * * * \\
(0.037)\end{array}$ & $\begin{array}{l}-3.428 * * * \\
(0.050)\end{array}$ & $\begin{array}{l}-3.906 * * * \\
(0.049)\end{array}$ & $\begin{array}{l}-3.387 * * * \\
(0.042)\end{array}$ \\
\hline$\gamma_{2}$ & $\begin{array}{l}1.113 * * * \\
(0.182)\end{array}$ & $\begin{array}{l}0.752 * * * \\
(0.279)\end{array}$ & $\begin{array}{l}-0.869 * * * \\
(0.328)\end{array}$ & $\begin{array}{l}-0.113 \\
(0.330)\end{array}$ & $\begin{array}{l}-0.099 \\
(0.323)\end{array}$ & $\begin{array}{l}-0.068 \\
(0.332)\end{array}$ \\
\hline $\mathrm{c}_{1 \gamma 0}$ & $\begin{array}{l}-0.305^{* * *} \\
(0.049)\end{array}$ & $\begin{array}{l}-0.482 * * * \\
(0.105)\end{array}$ & $\begin{array}{l}-0.147 * * \\
(0.074)\end{array}$ & $\begin{array}{l}-0.854 * * * \\
(0.089)\end{array}$ & $\begin{array}{l}-0.803 * * * \\
(0.092)\end{array}$ & $\begin{array}{l}-0.341 * * * \\
(0.069)\end{array}$ \\
\hline $\mathrm{c}_{1 \gamma 2}$ & $\begin{array}{l}0.453 * * \\
(0.194)\end{array}$ & $\begin{array}{l}-0.320 \\
(0.319)\end{array}$ & $\begin{array}{l}2.897 * * * \\
(0.405)\end{array}$ & $\begin{array}{l}1.464 * * * \\
(0.389)\end{array}$ & $\begin{array}{l}2.946 * * * \\
(0.404)\end{array}$ & $\begin{array}{l}1.384 * * * \\
(0.378)\end{array}$ \\
\hline$\gamma_{0}+\mathrm{c}_{1 \gamma 0}$ & $\begin{array}{l}-3.252 * * * \\
(0.196)\end{array}$ & $\begin{array}{l}-4.270 * * * \\
(0.069)\end{array}$ & $\begin{array}{l}-4.169 * * * \\
(0.064)\end{array}$ & $\begin{array}{l}-4.282 * * * \\
(0.074)\end{array}$ & $\begin{array}{l}-4.709^{* * *} \\
(0.077)\end{array}$ & $\begin{array}{l}-3.729 * * * \\
(0.055)\end{array}$ \\
\hline$\gamma_{2}+\mathrm{c}_{1 \gamma 2}$ & $\begin{array}{l}1.567 * * * \\
(0.157) \\
\end{array}$ & $\begin{array}{l}0.432 * * * \\
(0.155)\end{array}$ & $\begin{array}{l}2.029 * * * \\
(0.238)\end{array}$ & $\begin{array}{l}1.351 * * * \\
(0.205)\end{array}$ & $\begin{array}{l}2.847 * * * \\
(0.243)\end{array}$ & $\begin{array}{l}1.316^{* * *} \\
(0.182)\end{array}$ \\
\hline $\mathrm{c}_{2 \gamma 0}$ & $\begin{array}{l}1.658 * * * \\
(0.125)\end{array}$ & $\begin{array}{l}1.236 * * * \\
(0.151)\end{array}$ & $\begin{array}{l}3.002 * * * \\
(0.204)\end{array}$ & $\begin{array}{l}4.236 * * * \\
(1.182)\end{array}$ & $\begin{array}{l}3.806 * * * \\
(0.765)\end{array}$ & $\begin{array}{l}2.998 * * * \\
(0.205)\end{array}$ \\
\hline $\mathrm{c}_{2 \gamma 2}$ & $\begin{array}{l}-2.843 * * * \\
(0.499)\end{array}$ & $\begin{array}{l}-1.355^{*} \\
(0.884)\end{array}$ & $\begin{array}{l}-9.861 * * * \\
(0.795)\end{array}$ & $\begin{array}{l}-12.37 * * * \\
(4.448)\end{array}$ & $\begin{array}{l}-10.39 * * * \\
(3.072)\end{array}$ & $\begin{array}{l}-7.977 * * * \\
(0.631)\end{array}$ \\
\hline$\gamma_{0}+\mathrm{c}_{1 \gamma 0}+\mathrm{c}_{2 \gamma 0}$ & $\begin{array}{l}-1.594 * * * \\
(0.238)\end{array}$ & $\begin{array}{l}-3.034 * * * \\
(0.135)\end{array}$ & $\begin{array}{l}-1.167 * * \\
(0.194)\end{array}$ & $\begin{array}{l}-0.046 \\
(1.179)\end{array}$ & $\begin{array}{l}-0.904 \\
(0.761)\end{array}$ & $\begin{array}{l}-0.731 * * * \\
(0.199)\end{array}$ \\
\hline$\gamma_{2}+c_{1 \gamma 2}+c_{2 \gamma 2}$ & $\begin{array}{l}-1.276^{* * * *} \\
(0.482)\end{array}$ & $\begin{array}{l}-0.923 \\
(0.870)\end{array}$ & $\begin{array}{l}-7.832 * * * \\
(0.758)\end{array}$ & $\begin{array}{l}-11.02 * * * \\
(4.443)\end{array}$ & $\begin{array}{l}-7.538 * * * \\
(3.062)\end{array}$ & $\begin{array}{l}-6.662 * * * \\
(0.604)\end{array}$ \\
\hline $\begin{array}{l}\chi^{2} \text { statistic for } \\
\mathrm{H} 0: \mathrm{c}_{\mathrm{i} \gamma \mathrm{j}}=0\end{array}$ & $857.62 * * *$ & $251.87 * * *$ & $343.59 * * *$ & $284.32 * * *$ & $450.26^{* * *}$ & $253.96 * * *$ \\
\hline \multicolumn{7}{|l|}{ Eq. (4’) } \\
\hline$\delta_{0}$ & $\begin{array}{l}-4.400 * * * \\
(0.117)\end{array}$ & $\begin{array}{l}-3.940 * * * \\
(0.103)\end{array}$ & $\begin{array}{l}-3.767 * * * \\
(0.050)\end{array}$ & $\begin{array}{l}-3.518 * * * \\
(0.138)\end{array}$ & $\begin{array}{l}-3.891 * * * \\
(0.118)\end{array}$ & $\begin{array}{l}-3.368 * * * \\
(0.040)\end{array}$ \\
\hline$\delta_{2}$ & $\begin{array}{l}3.006 * * * \\
(0.348)\end{array}$ & $\begin{array}{l}1.344 * * \\
(0.738)\end{array}$ & $\begin{array}{l}6.726 * * * \\
(0.459)\end{array}$ & $\begin{array}{l}2.625 * * * \\
(0.860)\end{array}$ & $\begin{array}{l}4.072 * * * \\
(1.162)\end{array}$ & $\begin{array}{l}3.743 * * * \\
(0.466)\end{array}$ \\
\hline $\mathrm{c}_{1 \delta 0}$ & $\begin{array}{l}-0.345^{* * *} \\
(0.052)\end{array}$ & $\begin{array}{l}-0.449 * * * \\
(0.113)\end{array}$ & $\begin{array}{l}-0.399 * * * \\
(0.244)\end{array}$ & $\begin{array}{l}-0.531 * * * \\
(0.145)\end{array}$ & $\begin{array}{l}-0.284 * * \\
(0.133)\end{array}$ & $\begin{array}{l}-0.200 * * * \\
(0.057)\end{array}$ \\
\hline $\mathrm{c}_{1 \delta 2}$ & $\begin{array}{l}-0.648^{*} \\
(0.430)\end{array}$ & $\begin{array}{l}-0.322 \\
(0.883)\end{array}$ & $\begin{array}{l}-0.627 \\
(0.569)\end{array}$ & $\begin{array}{l}0.257 \\
(0.982)\end{array}$ & $\begin{array}{l}0.962 \\
(1.298)\end{array}$ & $\begin{array}{l}1.242 * * \\
(0.600)\end{array}$ \\
\hline$\delta_{0}+c_{1 \delta 0}$ & $\begin{array}{l}-4.745 * * * \\
(0.130)\end{array}$ & $\begin{array}{l}-4.388 * * * \\
(0.047)\end{array}$ & $\begin{array}{l}-4.166 * * * \\
(0.051)\end{array}$ & $\begin{array}{l}-4.049 * * * \\
(0.046)\end{array}$ & $\begin{array}{l}-4.175 * * * \\
(0.062)\end{array}$ & $\begin{array}{l}-3.568 * * * \\
(0.040)\end{array}$ \\
\hline$\delta_{2}+c_{1 \delta 2}$ & $\begin{array}{l}2.358 * * * \\
(0.252) \\
\end{array}$ & $\begin{array}{l}1.022 * * \\
(0.484)\end{array}$ & $\begin{array}{l}6.099 * * * \\
(0.336) \\
\end{array}$ & $\begin{array}{l}2.882 * * * \\
(0.474)\end{array}$ & $\begin{array}{l}5.035 * * * \\
(0.579) \\
\end{array}$ & $\begin{array}{l}4.985 * * * \\
(0.375)\end{array}$ \\
\hline $\mathrm{c}_{2 \delta 0}$ & $\begin{array}{l}1.415 * * * \\
(0.047)\end{array}$ & $\begin{array}{l}1.591 * * * \\
(0.068)\end{array}$ & $\begin{array}{l}1.910 * * * \\
(0.084)\end{array}$ & $\begin{array}{l}1.463 * * * \\
(0.125)\end{array}$ & $\begin{array}{l}1.482 * * * \\
(0.095)\end{array}$ & $\begin{array}{l}1.396 * * * \\
(0.080)\end{array}$ \\
\hline $\mathrm{c}_{2 \delta 2}$ & $\begin{array}{l}-4.166 * * * \\
(0.470)\end{array}$ & $\begin{array}{l}-3.104 * * \\
(1.793)\end{array}$ & $\begin{array}{l}-8.580 * * * \\
(0.473)\end{array}$ & $\begin{array}{l}-5.841 * * * \\
(1.712)\end{array}$ & $\begin{array}{l}-5.853 * * * \\
(1.689)\end{array}$ & $\begin{array}{l}-7.234 * * * \\
(0.548)\end{array}$ \\
\hline$\delta_{0}+c_{1 \delta 0}+c_{2 \delta 0}$ & $\begin{array}{l}-3.330 * * * \\
(0.132)\end{array}$ & $\begin{array}{l}-2.797 * * * \\
(0.050)\end{array}$ & $\begin{array}{l}-2.256 * * * \\
(0.066)\end{array}$ & $\begin{array}{l}-2.586 * * * \\
(0.116) \\
\end{array}$ & $\begin{array}{l}-2.693 * * * \\
(0.072)\end{array}$ & $\begin{array}{l}-2.172 * * * \\
(0.069)\end{array}$ \\
\hline$\delta_{2}+c_{1 \delta 2}+c_{2 \delta 2}$ & $\begin{array}{l}-1.808 * * * \\
(0.461)\end{array}$ & $\begin{array}{l}-2.082 \\
(1.726) \\
\end{array}$ & $\begin{array}{l}-2.481 * * * \\
(0.333)\end{array}$ & $\begin{array}{l}-2.959 * * \\
(1.645) \\
\end{array}$ & $\begin{array}{l}-0.819 \\
(1.587) \\
\end{array}$ & $\begin{array}{l}-2.249 * * * \\
(0.400)\end{array}$ \\
\hline $\begin{array}{l}\chi^{2} \text { statistic for } \\
\mathrm{H} 0: \mathrm{c}_{\mathrm{i} \delta \mathrm{j}}=0\end{array}$ & $1087.6 * * *$ & $578.90 * * *$ & $647.36 * * *$ & $260.45 * * *$ & $267.44 * * *$ & $320.35 * * *$ \\
\hline $\begin{array}{l}\text { Note: The sample } \\
\text { represent levels o } \\
\text { for all portfolios. } \\
\text { MIDQUAR, whil } \\
\text { significance tests }\end{array}$ & two breaks & nd Decen & 2011. Sta & $=c_{1 \gamma 2}=c_{2 \gamma 0}=c$ & and $c_{1 \delta 0}=c$ & $\begin{array}{l}\text { and } * \\
1 \text { is May } 2004 \\
\text { and } \\
\text { nt } \\
c_{2 \delta 0}=c_{2 \delta 2}=0 .\end{array}$ \\
\hline
\end{tabular}


Table 6 Estimates of Eq. (5) by the Markov two-state regime-switching technique

\begin{tabular}{|c|c|c|c|c|c|}
\hline & ZERO & FULPRI & BOTQUAR & MIDQUAR & UPPQUAR \\
\hline$\gamma_{01}$ & $\begin{array}{l}-2.971 * * * \\
(0.039)\end{array}$ & $\begin{array}{l}-3.967 * * * \\
(0.023)\end{array}$ & $\begin{array}{l}-2.834 * * * \\
(0.060)\end{array}$ & $\begin{array}{l}-2.366 * * * \\
(0.064)\end{array}$ & $\begin{array}{l}-2.433 * * * \\
(0.061)\end{array}$ \\
\hline$\gamma_{21}$ & $\begin{array}{l}-1.039 * * * \\
(0.089)\end{array}$ & $\begin{array}{l}1.321 * * * \\
(0.123)\end{array}$ & $\begin{array}{l}-0.154 \\
(0.236)\end{array}$ & $\begin{array}{l}-1.524 * * * \\
(0.191)\end{array}$ & $\begin{array}{l}-0.831 * * * \\
(0.163)\end{array}$ \\
\hline$\gamma_{02}$ & $\begin{array}{l}-3.754 * * * \\
(0.076)\end{array}$ & $\begin{array}{l}-3.756^{* * *} \\
(0.230)\end{array}$ & $\begin{array}{l}-3.694 * * * \\
(0.057)\end{array}$ & $\begin{array}{l}-4.043 * * * \\
(0.044)\end{array}$ & $\begin{array}{l}-3.412 * * * \\
(0.044)\end{array}$ \\
\hline$\gamma_{22}$ & $\begin{array}{l}-1.222 * * * \\
(0.311)\end{array}$ & $\begin{array}{l}1.411 \\
(0.906)\end{array}$ & $\begin{array}{l}0.156 \\
(0.201)\end{array}$ & $\begin{array}{l}-0.115 \\
(0.261)\end{array}$ & $\begin{array}{l}-0.437 * \\
(0.251)\end{array}$ \\
\hline$\sigma_{1}$ & $\begin{array}{l}0.023 * * * \\
(0.005)\end{array}$ & $\begin{array}{l}0.021 * * * \\
(0.004)\end{array}$ & $\begin{array}{l}0.007 * * * \\
(0.002)\end{array}$ & $\begin{array}{l}0.021 * * * \\
(0.004)\end{array}$ & $\begin{array}{l}0.010 * * * \\
(0.003)\end{array}$ \\
\hline$\sigma_{2}$ & $\begin{array}{l}0.075 * * * \\
(0.014)\end{array}$ & $\begin{array}{l}0.328 * * * \\
(0.061)\end{array}$ & $\begin{array}{l}0.114^{* * * *} \\
(0.017)\end{array}$ & $\begin{array}{l}0.076^{* * *} \\
(0.012)\end{array}$ & $\begin{array}{l}0.062 * * * \\
(0.010)\end{array}$ \\
\hline$P(1,1)$ & $\begin{array}{l}0.97 * * * \\
(0.020)\end{array}$ & $\begin{array}{l}0.979 * * * \\
(0.018)\end{array}$ & $\begin{array}{l}0.982 * * * \\
(0.022)\end{array}$ & $\begin{array}{l}0.972 * * * \\
(0.021)\end{array}$ & $\begin{array}{l}0.968 * * * \\
(0.025)\end{array}$ \\
\hline $\mathrm{P}(1,2)$ & $\begin{array}{l}0.037 * \\
(0.022)\end{array}$ & $\begin{array}{l}0.012 \\
(0.013) \\
\end{array}$ & $\begin{array}{l}0.016 \\
(0.012) \\
\end{array}$ & $\begin{array}{l}0.021 \\
(0.015) \\
\end{array}$ & $\begin{array}{l}0.002 \\
(0.015) \\
\end{array}$ \\
\hline $\mathrm{RCM}$ & 3.7588 & 3.494 & 1.5638 & 1.4113 & 2.6977 \\
\hline $\begin{array}{l}\text { No. iterations } \\
\text { to achieve } \\
\text { convergence }\end{array}$ & 20 & 15 & 27 & 29 & 41 \\
\hline
\end{tabular}

Note: The sample period is July 2001 and December 2011.

$* * *, * *$ and $*$ represent significance levels at $1 \%, 5 \%$ and $10 \%$ respectively for a one-tailed test. $\sigma_{1}$ and $\sigma_{2}$ are standard deviations of the regression residuals in regimes 1 and 2 respectively.

$P(i, j)$ are estimated transition probabilities for switching from regime $j$ to regime $i$.

$\mathrm{RCM}$ is the regime classification measure, $R C M=400 \times \frac{1}{T} \sum_{t=1}^{T} p_{1 t}\left(1-p_{1 t}\right)$, devised by Ang and

Bekaert (2002) for the case of two states. $\mathrm{p}_{1 \mathrm{t}}$ is the probabilities for regime 1 being in force at each point in time. A value of 0 means perfect classification while a value of 100 implies failure to classify. 
Table 7 Estimates of Eq. (5') by the Markov two-state regime-switching technique

\begin{tabular}{|c|c|c|c|c|c|}
\hline & ZERO & FULPRI & BOTQUAR & MIDQUAR & UPPQUAR \\
\hline$\delta_{01}$ & $\begin{array}{l}-2.779 * * * \\
(0.034)\end{array}$ & $\begin{array}{l}-2.353 * * * \\
(0.054)\end{array}$ & $\begin{array}{l}-4.159 * * * \\
(0.044)\end{array}$ & $\begin{array}{l}-2.710 * * * \\
(0.026)\end{array}$ & $\begin{array}{l}-2.146 * * * \\
(0.052)\end{array}$ \\
\hline$\delta_{21}$ & $\begin{array}{l}0.182 \\
(1.752)\end{array}$ & $\begin{array}{l}-2.581 * * * \\
(0.268)\end{array}$ & $\begin{array}{l}2.153 * * * \\
(0.429)\end{array}$ & $\begin{array}{l}-1.456^{* * * *} \\
(0.026)\end{array}$ & $\begin{array}{l}-2.191 * * * \\
(0.300)\end{array}$ \\
\hline$\delta_{02}$ & $\begin{array}{l}-4.236^{* * *} \\
(0.040)\end{array}$ & $\begin{array}{l}-4.026^{* * *} \\
(0.028)\end{array}$ & $\begin{array}{l}-3.180^{* * *} \\
(0.040)\end{array}$ & $\begin{array}{l}-4.216^{* * *} \\
(0.046)\end{array}$ & $\begin{array}{l}-3.467 * * * \\
(0.028)\end{array}$ \\
\hline$\delta_{22}$ & $\begin{array}{l}0.011^{* * *} \\
(0.358)\end{array}$ & $\begin{array}{l}4.530 * * * \\
(0.227)\end{array}$ & $\begin{array}{l}4.490^{* * *} \\
(0.320)\end{array}$ & $\begin{array}{l}2.369^{* * * *} \\
(0.506)\end{array}$ & $\begin{array}{l}3.542 * * * \\
(0.305)\end{array}$ \\
\hline$\sigma_{1}$ & $\begin{array}{l}0.024 * * * \\
(0.006)\end{array}$ & $\begin{array}{l}0.019 * * * \\
(0.004)\end{array}$ & $\begin{array}{l}0.036^{* * *} \\
(0.009)\end{array}$ & $\begin{array}{l}0.017 * * * \\
(0.003)\end{array}$ & $\begin{array}{l}0.022 * * * \\
(0.005)\end{array}$ \\
\hline$\sigma_{2}$ & $\begin{array}{l}0.080 * * * \\
(0.011)\end{array}$ & $\begin{array}{l}0.043 * * * \\
(0.007)\end{array}$ & $\begin{array}{l}0.063^{* * * *} \\
(0.011)\end{array}$ & $\begin{array}{l}0.075^{* * *} \\
(0.012)\end{array}$ & $\begin{array}{l}0.042 * * * \\
(0.007)\end{array}$ \\
\hline $\mathrm{P}(1,1)$ & $\begin{array}{l}0.989 * * * \\
(0.015)\end{array}$ & $\begin{array}{l}0.991 * * * \\
(0.012)\end{array}$ & $\begin{array}{l}0.945 * * * \\
(0.034)\end{array}$ & $\begin{array}{l}0.992 * * * \\
(0.009)\end{array}$ & $\begin{array}{l}0.991 * * * \\
(0.011)\end{array}$ \\
\hline $\mathrm{P}(1,2)$ & $\begin{array}{l}0.007 \\
(0.008)\end{array}$ & $\begin{array}{l}0.007 \\
(0.009) \\
\end{array}$ & $\begin{array}{l}0.022 \\
(0.015)\end{array}$ & $\begin{array}{l}0.008 \\
(0.009) \\
\end{array}$ & $\begin{array}{l}0.007 \\
(0.008) \\
\end{array}$ \\
\hline $\mathrm{RCM}$ & 0.7998 & 1.756 & 3.7428 & 1.0505 & 1.4160 \\
\hline $\begin{array}{l}\text { No. iterations to } \\
\text { achieve } \\
\text { convergence }\end{array}$ & 20 & 28 & 14 & 22 & 21 \\
\hline
\end{tabular}

Note: The sample period is July 2001 and December 2011.

$* * *, * *$ and $*$ represent significance levels at $1 \%, 5 \%$ and $10 \%$ respectively for a one-tailed test.

$\sigma_{1}$ and $\sigma_{2}$ are standard deviations of the regression residuals in regimes 1 and 2 respectively.

$P(i, j)$ are estimated transition probabilities for switching from regime $j$ to regime $i$.

$\mathrm{RCM}$ is the regime classification measure, $R C M=400 \times \frac{1}{T} \sum_{t=1}^{T} p_{1 t}\left(1-p_{1 t}\right)$, devised by Ang and

Bekaert (2002) for the case of two states. $\mathrm{p}_{1 \mathrm{t}}$ is the probabilities for regime 1 being in force at each point in time. A value of 0 means perfect classification while a value of 100 implies failure to classify. 
Figure 1 Average percentages of state ownership for firms falling in the top, middle and bottom quartiles of state ownership distribution over 2000-2011

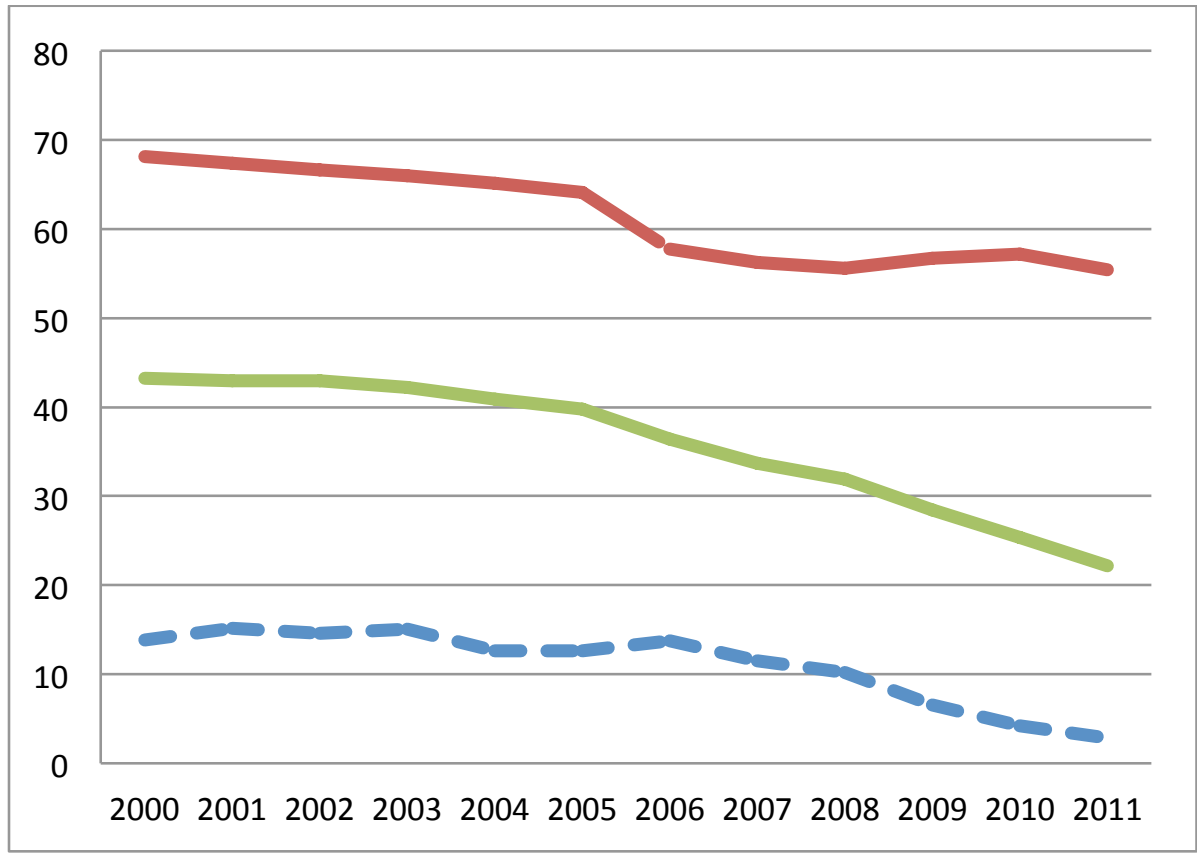


Figure 2 Market value-weighted average share prices (in Chinese Yuan)

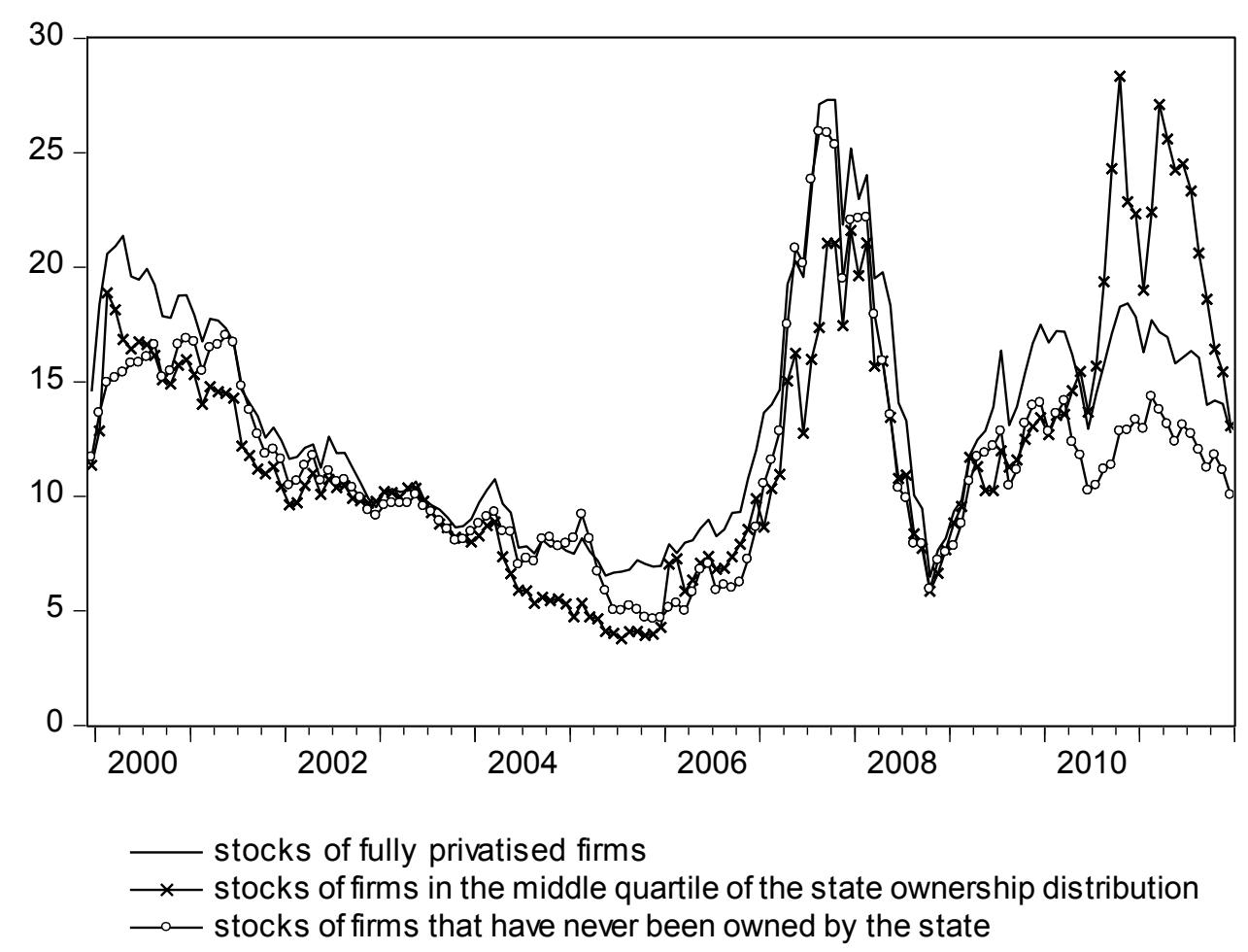


Figure 3 Time-varying systematic risks during July 2001 and December 2011

Panel $A: \beta^{G}$ and $\beta^{\mathrm{N}-\mathrm{G}}$
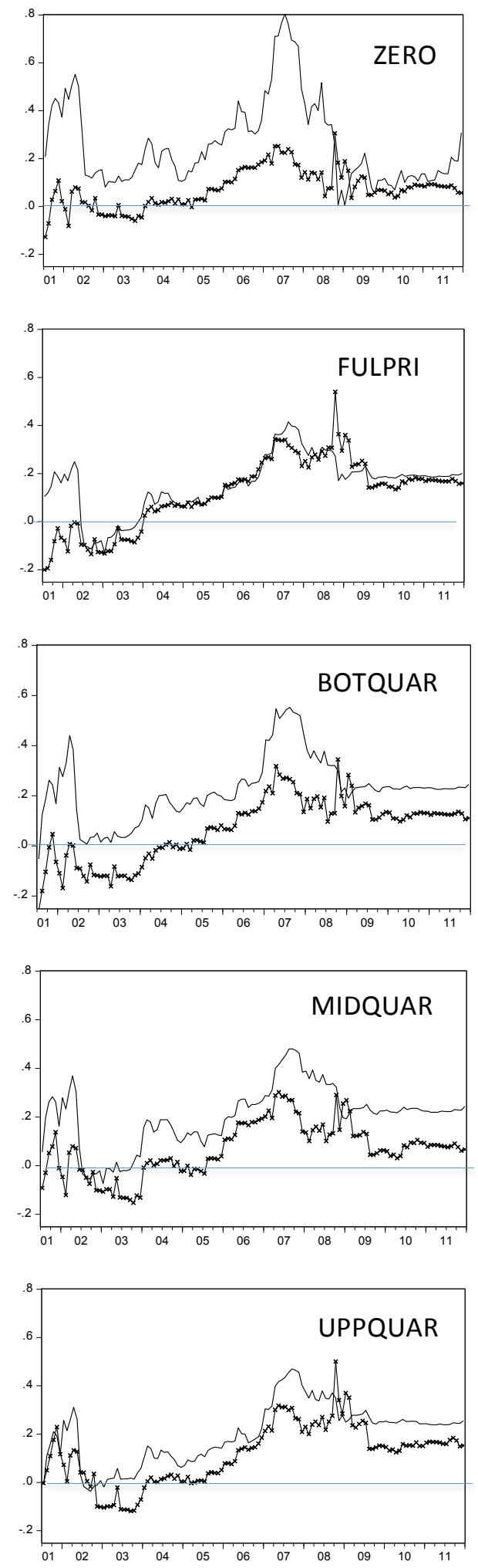

Panel B: $\beta^{\mathrm{N}}$ and $\beta^{\mathrm{G}-\mathrm{N}}$
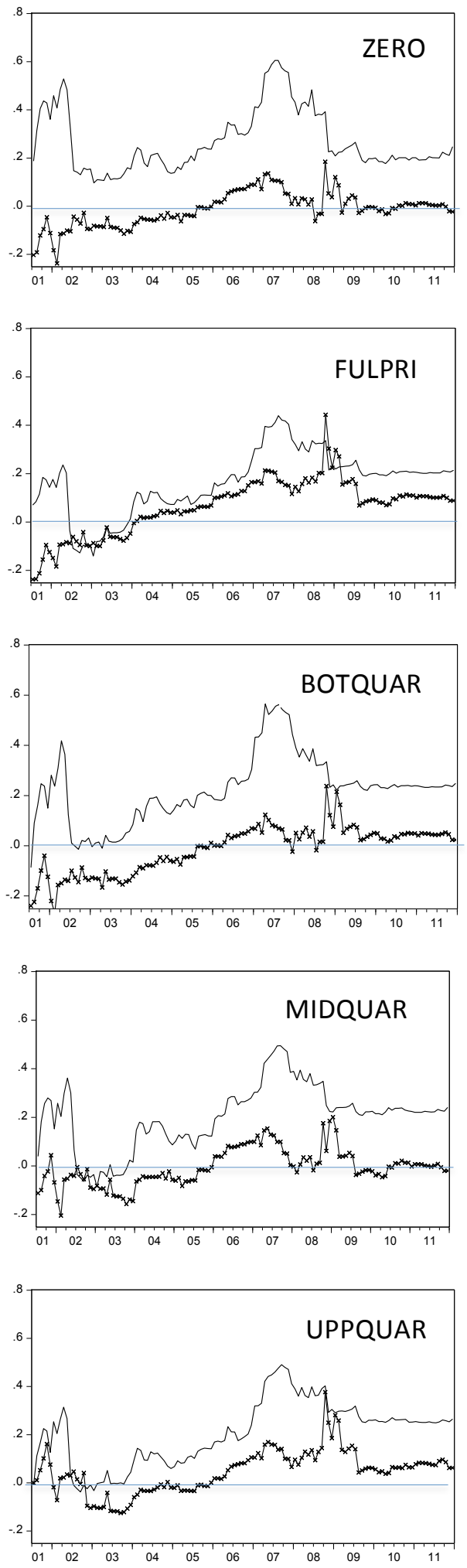

Note: Lines in $-\mathrm{x}-\mathrm{X}-\mathrm{x}-$ represent the unorthogonal global systematic risk $\left(\beta^{G}\right.$ in panel $\left.A\right)$ or orthogonal global systematic risk $\left(\beta^{G-N}\right.$ in panel B) and those in — are the orthogonal national systematic risk $\left(\beta^{N-G}\right.$ in panel $\left.A\right)$ or unorthogonal national systematic risk ( $\beta^{\mathrm{N}}$ in panel B). The systematic risks in panel A are estimated from Eqs. (2.2) and (2.3), while those in panel B are estimated from Eqs. (2.2') and (2.3') by the Kalman smoothing technique. 
Figure 4 Smoothed probabilities of volatility regimes generated by the recursive representation of Gray (1996)

Panel A: Eq. (5)
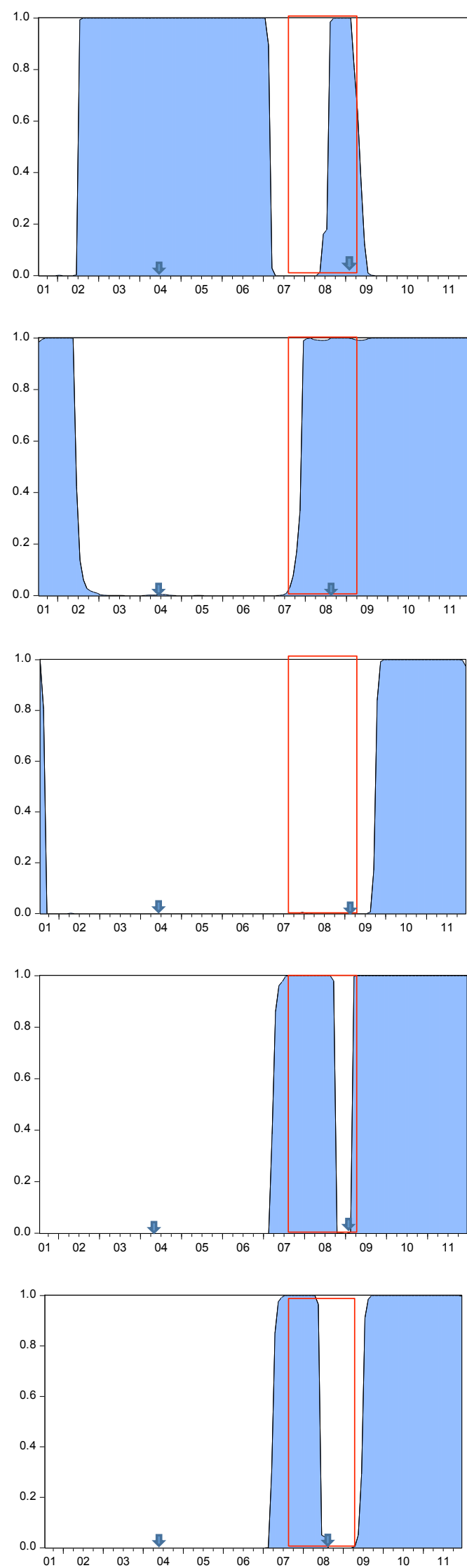

Panel B: Eq.(5')

ZERO

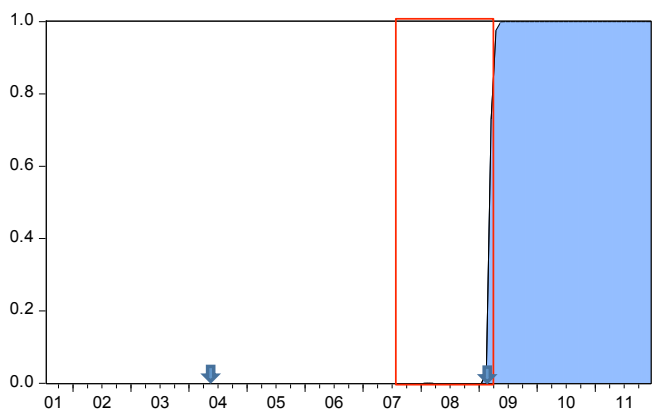

FULPRI

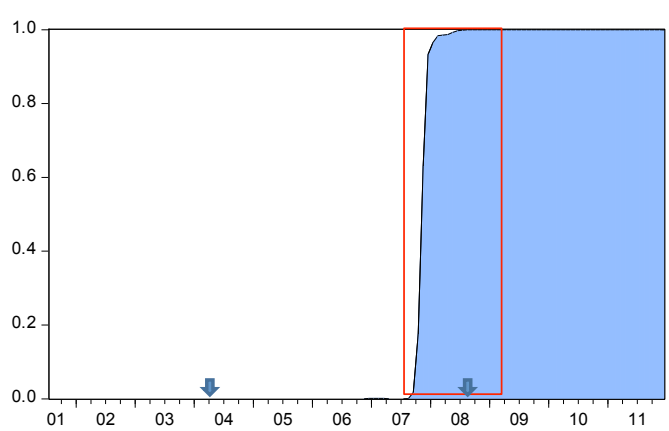

BOTQUAR

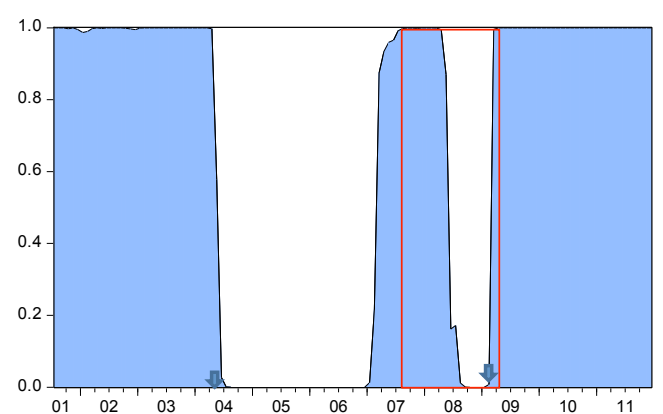

MIDQUAR

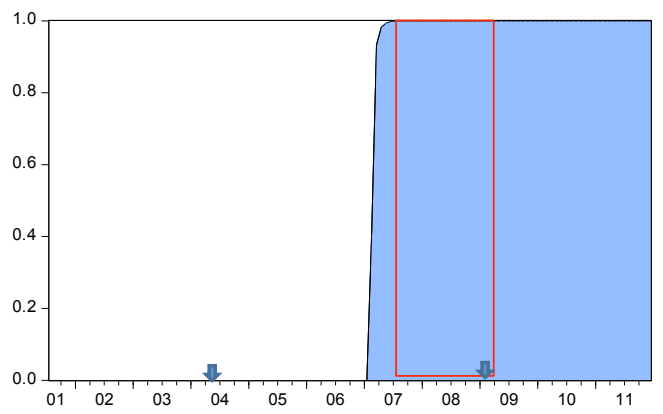

UPPQUAR

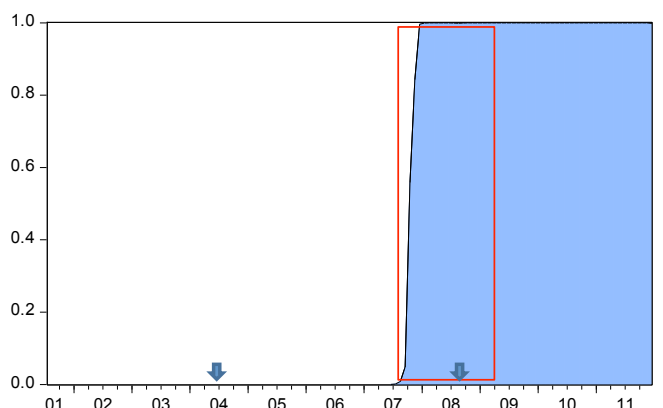

Note: Shaded areas represent high-volatility regimes. The arrows indicate the major break points identified by

Bai-Perron algorithm (2003). 